\title{
ŽUPNI (KAPTOLSKI) ARHIV BARBANA, S OSVRTOM NA PODATKE O KANONIKU PETRU STANKOVIĆU *
}

\author{
Jakov JELINČIĆ \\ Istarskih narodnjaka 18, Pazin \\ jakov.jelincic@gmail.com
}

\author{
UDK 2-774(497.571Barban): \\ 929.53>:2-722Stanković P. \\ Stručni rad
}

\begin{abstract}
Autor u prilogu govori o brizi Katoličke Crkve za očuvanje arhivskoga gradiva i o važnosti samih crkvenih arhiva. Nabraja razne vrste crkvenih arhiva i govori o njihovoj važnosti za proučavanje prošlosti. Posebno naglašava brigu poglavarâ Katoličke Crkve za crkvene arhive. Daje osnovne obavijesti o sačuvanosti gradiva barbanskoga kaptolskog arhiva te o važnosti njegovih pojedinih dijelova, naglašavajući važnost knjiga pisama, knjiga oporuka, knjige raznih ugovora, knjiga kaptolskih zakupa te raznih spisa (opći, vjenčani, računski...) koje još treba pregledati i evidentirati te daje osnovne informacije o popisivanju crkvenih arhiva na području Porečke i Pulske biskupije. Posebno navodi neke podatke iz knjige sadržaja oporuka, knjige registra pisama i matičnih knjiga. Daje razne podatke iz matičnih knjiga o kanoniku Petru Stankoviću te njegovoj užoj i široj obitelji. Na kraju u izvorniku i u prijevodu donosi dva priloga: povelju o posveti crkve i inventar crkvenoga namještaja i liturgijskoga ruha iz 1750. godine.
\end{abstract}

Ključne riječi: arhiv, Barban, Crkva, gradivo, kaptol, kanonik, matične knjige, Petar Stanković

Keywords: Archives, Barban, Church, archives, chapter, canon, registers, Petar Stanković

Parole chiave: archivio, Barbana, Chiesa, materiale, capitolo, canonico, registri anagrafici, Petar Stanković

Čuvanje i zaštita dokumenata nastalih djelovanjem crkvenih ustanova oduvijek su bili u žarištu brige Katoličke Crkve i njenih vrhovnih poglavara. Rezultat te brige nisu samo vatikanski arhivi nego i arhivi nadbiskupija, biskupija, kaptola, dekanata, župa, kapelanija, redovničkih i drugih crkvenih ustanova. Bez gradiva navedenih ustanova mnoge bi činjenice iz povijesti ostale zapretane pod prašinom minulih vremena. Treba, naime, znati da je

\footnotetext{
Ovaj je rad proširena verzija predavanja održanoga u Barbanu 3. prosinca 2011. na znanstvenom skupu prigodom 310. obljetnice gradnje i posvete župne crkve svetoga Nikole u Barbanu. Ovom prigodom zahvaljujem gospodinu župniku barbanskom vlč. Miroslavu Paraniaku na gostoprimstvu i prijateljskoj susretljivosti prigodom istraživanja u župnom arhivu, kao i kolegicama dr. sc. Danijeli Doblanović i Maji Cerić, prof., u ono vrijeme djelatnicama Državnog arhiva u Pazinu, na tehničkoj pomoći.
} 
Crkva, naročito u prošlosti, imala ogroman utjecaj na sve sfere života, kao i činjenicu da su ti arhivi često puno bolje sačuvani nego paralelni arhivi civilnih vlasti.

Zaštita arhivskoga gradiva predmet je crkvenoga prava te Zbornik crkvenoga prava (Codex iuris canonici), onaj iz 1917., ali i onaj iz 1983., donosi stroge propise o tom pitanju. S tim u svezi kanon 535, paragraf 4., propisuje sljedeće: »Neka u svakoj župi bude pismohrana ili arhiv, u kojem se čuvaju župne knjige zajedno s biskupskim poslanicama i drugim ispravama koje treba da se čuvaju radi potrebe ili koristi. Sve to treba da u vrijeme pohoda ili u drugo koje podobno vrijeme, pregleda dijecezanski biskup ili njegov ovlaštenik, a župnik neka pazi da to ne dođe u ruke nepozvanima. ${ }^{1}$

Treba, međutim, reći, da su biskupi i prije donošenja Zakonika, posebno od 1600. kada se počinju provoditi biskupske vizitacije župama, u pravilu svakih pet godina, kontrolirali čuvaju li se brižljivo matične i druge službene knjige i spisi u pojedinoj župi.

Spomenuh na početku brigu vrhovnih pastira Katoličke Crkve. Navodim ovdje samo nekoliko papa iz novijega vremena.

Predstojnika (prefekta) Vatikanskoga arhiva i Vatikanske knjižnice Achila Rattija, kasnijega papu Pija XI. (1922. - 1939.), milanski nadbiskup Giovanni Battista Montini, koji je i sam kasnije postao papom, uzevši ime Pavao VI. (1963. - 1978.), i sam zaljubljenik u arhive, komemorirao je na otvorenju Drugoga skupa crkvenih arhivista 1959. godine sljedećim riječima: „Ta ruka Pontifeksa, koja nije dopuštala da na marginama bude nabora te se činilo da želi izbrisati mrlje ili indiskretne znakove i gotovo liječiti razderotine i okrnjene rubove, davala je lekciju...; ...ne smiju se u takvo stanje dovesti te časne listine jer su one važni dokumenti crkvenoga života i daju im juridičku potvrdu, imaju u sebi nešto sveto, treba shvatiti koliko vrijede za povijest i kulturu. U njima su, nadalje, pravila i iskustva koja govore kako se ovi dokumenti trebaju čuvati i paziti i kako s njima treba rukovati; treba ih bolje upoznati i promatrati..."2 Treba reći da ovo nije pozdravni govor u pravom smislu riječi, što bi ga novoimenovani kardinal Montini, kao domaćin susreta, bio održao u svojstvu milanskoga nadbiskupa. On je, naime, održao uvodno predavanje (prolusione) pod naslovom: Gli archivi diocesani e gli archivi parrocchiali nell'ordinamento della Chiesa (Biskupijski i župni arhivi u crkvenom ustrojstvu).

O poimanju važnosti crkvenih arhiva jednoga drugog pape, Rattijeva nasljednika, velikoga Pija XII. (1939. - 1958.), govori i činjenica da je on osobno, kao papa, otvorio 5. studenoga 1957. prvi susret crkvenih arhivista u Rimu. Uvodni govor na tom prvom susretu crkvenih arhivista održao je kardinal Angelo Giuseppe Roncalli, poznatiji kao papa Ivan XXIII. (1958. - 1963.). Zanimljivo je napomenuti da je Roncalli objavio djelo u pet tomova u kojem donosi pastoralnu vizitaciju svetoga Karla Boromejskog Bergamskoj biskupiji, dakle, biskupiji iz koje potječe i sam Roncalli. Autor je napisao vrlo opsežan stručni uvod te mu se nadbiskup Montini divi i kaže kako je »Roncalli rijetkom ustrajnošću i zadivljuju-

Codex iuris canonici / Zakonik kanonskog prava, Glas Koncila, Zagreb, 1988., str. 247.

2 Giovanni Battista MONTINI, »Gli arhivi diocesani e gli archivi parrocchiali nell'ordinamento della Chiesa«, Archiva Ecclesiae, Anno II, Città del Vaticano, 1959., str. 43 (dalje: Archiva Ecclesiae). Napomena: svi prijevodi u ovom radu u verziji su J. Jelinčića. 
ćom prostodušnošću uspio ispreplesti brige jednoga papinskog predstavnika u inozemstvu s brigom jednoga osjetljivog i mukotrpnog arhivskog istraživanja, dajući tako primjer kako jedan vrlo visoki crkveni dostojanstvenik zna u isto vrijeme diplomatski djelovati i znanstveno raditi. $\ll^{3}$

\section{VRSTE CRKVENIH ARHIVA}

Osim vatikanskih arhiva, poznatih u cijelom svijetu, vjerojatno i najistraživanijih, odnosno najkorištenijih u povijesne svrhe, postoje, kako sam već naveo, biskupijski arhivi, kaptolski, dekanatski, župni, kapelanski i arhivi raznih crkvenih ustanova, naprimjer, bratovština, misijskih djela, Caritasa, drugih dobrotvornih ustanova, samostanski arhivi itd.

S obzirom na to da ovdje govorimo o kaptolskom (župnom) arhivu, samo nekoliko riječi o njima.

Katedralni su kaptoli djelovali u sklopu katedrale (biskupske stolne crkve) i bili su, donekle, pomoć biskupu.

Osim dvaju katedralnih kaptola (Poreč i Pula), na području su ovih biskupija postojali i tzv. zborni kaptoli. Oni su vodili župu, i to na način da bi jednoga od njih kao župnika imenovao biskup, a u isto je vrijeme, u pravilu, bio i prepozit kaptola. Na području su današnje Porečke i Pulske biskupije bili sljedeći kaptoli: Bale, Barban, Boljun (ranije), Buje, Buzet, Dvigrad/Kanfanar, Grožnjan, Labin Gornji, Motovun, Plomin (do 1840.), Roč, Rovinj, Sveti Lovreč i Vodnjan. Ruralni je kaptol djelovao u Medulinu (do 1564.) ${ }^{4}$ i po svemu sudeći u Gračišću ${ }^{5}$.

Ovdje treba spomenuti da su na području današnje Porečke i Pulske biskupije djelovale još i Pićanska i Novigradska biskupija sa svojim katedralnim kaptolima: Pićan i Novigrad.

Ukidanjem kaptolâ 1843. godine, dio je tih župa postao sjedištem dekanata. Tako su utemeljeni dekanati Buzet, Rovinj/Kanfanar, Poreč, Pula, Labin, Motovun, Umag i Vodnjan.

\section{POPISIVANJE GRADIVA CRKVENIH ARHIVA POREČKE I PULSKE BISKUPIJE}

Godine 1970., zalaganjem tadašnjega direktora Državnog arhiva u Pazinu (tada: Historijski arhiv), profesora Dražena Vlahova, započelo je sustavno popisivanje arhivskoga gradiva crkvenih arhiva. Biskup Dragutin Nežić, i sam povjesničar i arhivist, imenovao je

Archiva Ecclesiae I, Città del Vaticano, 1958., str. 45.

Marijan BARTOLIĆ - Ivan GRAH (ur.), Crkva u Istri, III. dop. izd. (stanje 1. lipnja 1998.), IKD »Juraj Dobrila« - »Josip Turčinović«, Pazin, 1999., str. 102.

5 Prigodom popisivanja gradiva župnoga arhiva u Gračišću 8. 1. 1971. Ivan Grah, župnik i biskupski izaslanik za crkvene arhive, i autor ovoga članka naišli su na knjigu Libro maestro [Glavna knjiga računa], 1711. - 1745. (297 listova). Autor članka ne sjeća se na temelju čega su ustanovili da se radi o kaptolskoj knjizi. 
kao svog izaslanika, svećenika Ivana Graha, župnika u Gračišću, a Dražen Vlahov arhivista, profesora Jakova Jelinčića.

Prvi dan popisivanja bio je 18. prosinca 1970. u Gračišću, a Barban je došao na red 30. travnja 1971. Pretpostavljajući da se radi o vrijednom gradivu, monsinjor Nežić većinu je gradiva barbanske župe prebacio u zgradu tadašnjega Pazinskog sjemeništa (danas: Pazinski kolegij - klasična gimnazija). Na sređivanju i popisivanju toga gradiva radili smo 30. travnja te 7., 22. i 23. lipnja 1971., a na preostalom gradivu, koje se nalazilo u župnom stanu, radili smo 26. studenoga 1975. Nakon sređivanja prvoga dijela napravili smo privremeni inventar, a nakon sređivanja drugoga dijela konačni inventar.

Veliki i međunarodno priznati stručnjak iz područja arhivistike, dr. h. c. Bernard Stu1li, tadašnji ravnatelj Hrvatskoga državnog arhiva (tada: Arhiv Hrvatske), rekao je da su rezultati ovoga rada - inventari - »zlata vrijedni«. Bio je to, a ostao je i do danas, jedinstveni pothvat ne samo u Hrvatskoj nego i cijeloj bivšoj državi. Kako nismo imali predloška (primjera kako treba raditi), sami smo ga napravili. Obišli smo 108 župa i posao završili u župi Boljun 28. listopada 1980., utrošivši ukupno svaki po 152 dana (151 i pol) rada na njima.

Naglašavam da smo sve arhive najosnovnije usustavili prema vrstama gradiva, a da bi za potpuno sređivanje trebalo više godina. Na svakom svežnju spisa i na svakoj knjizi nalazi se broj te se po inventaru istraživač lako može snaći.

U ovom se trenutku gradivo ne može istraživati jer za to ne postoji prikladan prostor, a problem je i zauzetost župnika jer istraživač ne može na gradivu raditi bez nazočnosti odgovorne osobe. Za takva je istraživanja potrebno odobrenje biskupa ordinarija.

\section{SAČUVANOST ŽUPNOGA (KAPTOLSKOG) ARHIVA}

Župa je osnovana 740. godine, a od početka 9. stoljeća do 1843. godine djelovao je zborni kaptol čiji je prepozit ujedno bio župnik. S obzirom na to da se radi o zbornom kaptolu, riječ je zapravo o jedinstvenom fondu sa serijama. Gradivo je popisano na sljedeći način i svakako ima »prostora« za njegovo preuređenje:

1 Knjige javnih pisama (1761. - 1923.)

2 Matične knjige krštenih (MKK) (1629. do danas)

2 a Knjige krizmanih (MKKr) (1744. do danas)

3 Matične knjige umrlih (MKU) (1669. do danas)

4 Matične knjige vjenčanih (MKV) (1669. do danas)

5 Stanje duša (19. i 20. st.)

6 Urudžbeni zapisnici (1815. do danas)

7 Glavne knjige računa (1874. do danas)

8 Dnevnici primitaka i izdataka (1848. - tekuća)

9 Blagajnički dnevnik (1863. - 1903.) 


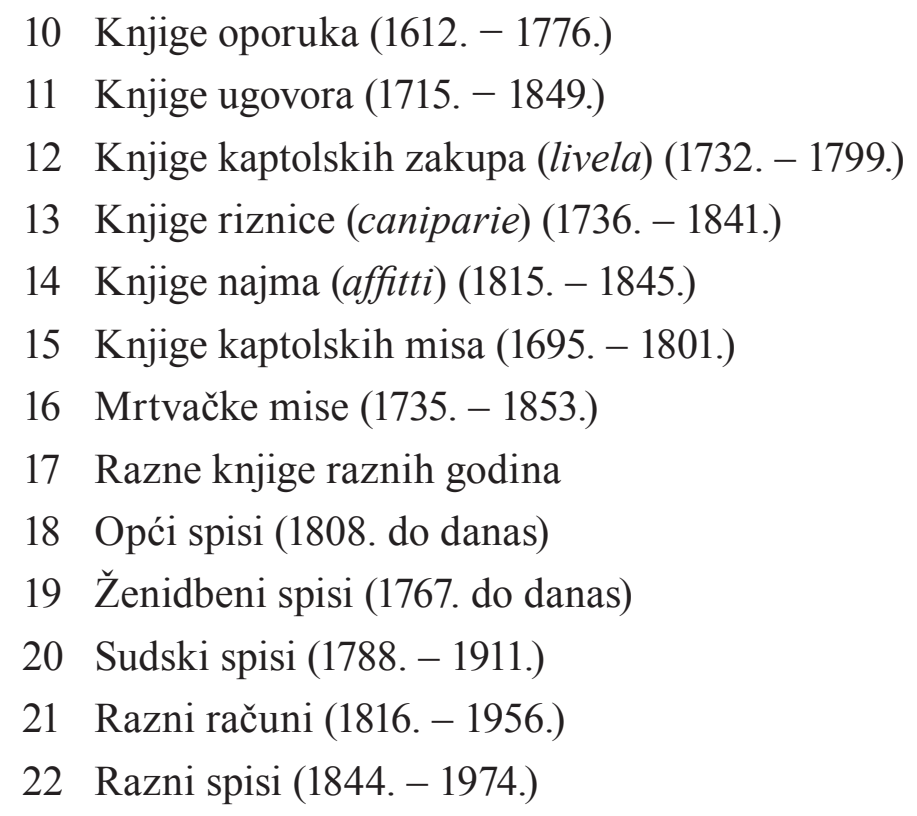

Treba reći da nije uvijek sačuvano gradivo za svaku godinu. No, glavnina je sačuvana.

Sami nazivi gradiva djeluju suhoparno, ali se čak i među knjigama misa, pa i knjigama računa, mogu kriti zanimljivi podatci o osobama, o imovinskim prilikama stanovnika i sl.

Ipak, naglašavam važnost sačuvanih matičnih knjiga. One nam govore o imenima, prezimenima, društvenom statusu, broju rođene djece; matice vjenčanih o mjestu odakle dolaze zaručnici ili zaručnice, o razlici u godinama; matice umrlih o starosti umrlih, o bolestima i drugim uzrocima smrti (ubojstva, nesreće i sl.). K ovima pribrajamo knjige krizmanih. Knjige, pak, stanja duša zbir su podataka iz svih navedenih matičnih knjiga.

Gradivo na koje bih upozorio jesu knjige javnih pisama, knjige oporuka, knjige raznih ugovora, knjige kaptolskih zakupa te razni spisi (opći, vjenčani, računski...) koje /spise/ još treba pregledati i evidentirati.

S obzirom na vremenski raspon djelovanja barbanskoga kaptola, ne možemo biti zadovoljni stupnjem sačuvanosti gradiva, međutim, daleko je bolje sačuvano od gradiva gospoštije.

Pokojni akademik Danilo Klen u svom radu »Arhiv Barbana i Raklja do njegove propasti 1893. godine«, nakon stručnoga uvoda donosi dva sačuvana inventara. Prvi je inventar napravio Josip Batel, a sažeo ga je, čini se, Tomaso Luciani. Inventar nosi naslov: Inventario degli atti, carte, danaro e mobili, esistenti nell'uffizio comunale di Barbana, assunto nel 1861. Drugi je inventar nastao prigodom primopredaje dužnosti načelnika Ivana Malabotića novom načelniku Josipu Batelu 15. svibnja 1861., a u njemu nalazimo i popis župnoga arhiva, uprave crkava i kaptolskoga arhiva, kao zasebnoga arhiva, i nosi naslov: Contenuto degli archivi comunale, parrocchiale, capitolare, e al(tri) di Barbana. ${ }^{6} \mathrm{~S}$ ob-

6 Danilo KLEN, »Arhiv Barbana i Raklja do njegove propasti 1893. godine«, Vjesnik historijskih arhiva u Rijeci i Pazinu, sv. XXIV, Rijeka - Pazin, 1981., str. 335-368. 
zirom na to da je barbanski općinski arhiv i dio feudalnoga arhiva, kako piše Klen, 1893. izgorio, onda župni arhiv dobiva na još većoj važnosti.

Budući da je u drugom inventaru popisano gradivo crkvenih ustanova, ovaj nam inventar pomaže kako bismo usporedili tadašnje sa sadašnjim stanjem. Danilo Klen prilog zaključuje ovim riječima: »Smatram da će objavljivanje inventara i popisa biti od koristi obrađivaču povijesti ovog dijela Istre, pružajući mu i nešto više od arhivskih podataka, o brizi i nebrizi za arhivalije, stavljajući pred njega opće natuknice za sliku života u tom hrvatskom selu. Nažalost, i u barbanskom se slučaju pokazalo da su tragove svoje prošlosti bolje čuvali zainteresirani feudalci i crkvene ustanove.«?

Treba ipak reći da se u Državnom arhivu u Rijeci čuvaju Knjiga terminacija feudalne jurisdikcije Barban - Rakalj (1576-1743) i Knjiga vizitacije feudalne jurisdikcije Barbana i Raklja iz godine 1767. Prvu je objavila Blanka Vučetić, ${ }^{8}$ a drugu dr. Mirko Zjačić ${ }^{9}$ u Vjesniku Državnoga arhiva u Rijeci.

Radi se o vrlo vrijednim knjigama iz kojih velikim dijelom možemo iščitavati dio barbanske i rakaljske povijesti.

\section{O GRADIVU}

Sadržaj gradiva ovoga arhiva nije moguće prikazati u jednom radu. Odlučio sam stoga dati samo nekoliko podataka iz gradiva, što ne znači uvijek da su oni najvažniji. No, svakako smatram da su Inventar crkvenoga namještaja i crkvenoga ruha (od kojih je gotovo sve sačuvano) i Povelja o posveti kolegijalne crkve svetoga Nikole vrijedni objavljivanja.

Upravo izvornike i prijevode ovih dvaju dokumenata prilažem na kraju ovoga rada, sa svim gramatičkim i pravopisnim osobitostima. Intervenirao sam jedino u interpunkcijama kako bi čitatelj koji razumije jezik kojim su pisani mogao lakše razumjeti tekst.

\section{Neki podatci o gradivu}

\section{Knjiga sadržaja oporuka}

U Knjizi sadržaja oporuka (Testamenti con Legati con Carte dal $n .^{\circ} 1$ sino $n .^{\circ} 140$, inv. br. 10,2) nalaze se sadržaji 427 raznih oporuka osoba koje su ostavljale dio svoga imetka kaptolu odnosno župi, uz obveze da za njih služe mise. Knjiga vrvi prezimenima oporučiteljâ i svjedokâ. Velikom se većinom radi o hrvatskim prezimenima. Dio se imenâ izvorno navodi kao hrvatska, a nema sumnje da su se i većina ostalih tako izgovarala.

Navodim samo dio prezimenâ - hrvatskih i talijanskih:

\section{Isto, str. 352.}

8 Blanka VUČETIĆ, »Knjiga terminacija feudalne jurisdikcije Barban - Rakalj (1576-1743)«, Vjesnik Državnoga arhiva u Rijeci, sv. II, Rijeka, 1954., str. 101-307.

9 Mirko ZJAČIĆ, »Knjiga vizitacije feudalne jurisdikcije Barbana i Raklja iz godine 1767.«, isto, str. 309490. 
Aničić (Anicich), Antončić (Antoncich), Baćac (Bachiaz), Belavić (Bellavich), Bilić (Billich), Blažina (Blasina), Bogović (Bogovich), Bošnjak (Bosgnach), Bratelić (Brattelich), Broskvar (Brosquar), Brozić (Brosich), Butković (Butcovich), Dragozet (Dragoset), Duplić (Duplich), Filipović (Filippovich), Franić (Franich), Franković (Francovich), Gašpe (Gaspe), Gergorović (Ghergorovich), Gletić (Gletich), Grgorinić (Ghergorinich), Jakša (Giaxa), Kalčić (Calcich), Kancelar (Cancellar), Klanica (Clanizza), Kolić (Collich), Kožljan (Cosglian), Kruhonja (Crucogna), Kuić (Cuich), Lovrinić (Lovrinich), Lukšić (Luxich), Manjadvorac (Magnadvoraz), Mirković (Mircovich), Nežić (Nesich), Paulić (Paulich), Percan (Perzan), Perčić (Percich), Poropat, Rajko (Raico), Rebić (Rebich), Rojnić (Roinich), Rosić (Rossich), Ružić (Rusich), Šepić (Sepich), Škampić (Scampicchio), Šugar (Sugar), Tomović (Tomovich), Vicić (Vicich), Vlačić (Vlacich), Vladislović (Vladislovich), Vlaković (Vlacovich), Vukota (Vucotta), Želesko (Selesco)...

Battel, Borina, Cacco, Celia, del Prato, Faraguna, Fedel, Fumetta, Manzoni, Mazzucca, Moro, Polo, Quaranta, Zaratin... ${ }^{10}$

Navodim i šest prezimena uz naznaku godine u kojoj se pojavljuju: 1573. Burul, 1575. Svetinić, 1581. Zangrandić, 1582. Beloglavac, 1583. Svetić i 1589. Teković..."

Smatram da ova knjiga, ali i još neke iz sačuvanoga gradiva u župnom arhivu, kada to budu dopuštale financijske i kadrovske prilike, naravno, uz odobrenje vlasnika gradiva, tj. Biskupskoga ordinarijata i barbanske župe, zavrjeđuju objavljivanje.

\section{Registar pisama}

Jedna je od vrednijih sačuvanih knjiga svakako i Registar pisama (Registro di lettere Parrocchiali, Capitolari, Amministrazione Parocchiale, e miste da carte 1 a carte 223 di numeri progressivi Dal N. 1 - al N. 915 ) koju je za vrijeme svoga upravljanja župom vodio barbanski kanonik Petar Stanković, o kojem se nešto više govori u kasnijem tekstu.

Naslov unutar knjige glasi: Registro di Lettere Parocchiali di me Pietro Stancovich canonico seniore $f$. $f$. di arciprete e parroco per la morte del inclito signor don Martino Battel canonico, parroco ed arciprete di questa insigne colleggiata di San Niccolò di Barbana seguita nel giorno 30 agosto 1827 - Registar župnih pisama što ga pišem ja, Petar Stanković, kanonik senior i v. d. župnika i arcipreta ove časne kolegijalne (crkve) svetoga Nikole u Barbanu, zbog smrti uvaženoga gospodina Martina Batela koja je nastupila 30. kolovoza 1827. (fol. 2r).

Ova knjiga sadrži više važnih podataka iz vremena u kojem je nastala (30. 8. 1827. 15. 6. 1838.).

Donosim sadržaje samo nekih:

10 Dio se talijanskih prezimena oblikom kasnije kroatizirao (npr. Kvaranta i Macuka).

11 Vidi: Jakov JELINČIĆ, »Matične knjige župe Barban s posebnim osvrtom na matičnu knjigu krštenih (1815. - 1831.)«, Barbanski zapisi, sv. 1, u: Zbornik radova znanstvenog skupa »Barban i Barbanština od prapovijesti do danas« 2. memorijal Petra Stankovića, »Barban u srcu«, 2013., str. 71-201. 
- Stanković šalje odgovor biskupiji da župa Barban broji 2147 osoba nastanjenih u 403 kućna broja na području od 24 talijanske milje kvadratne.

- Župnikov je prihod 58:46 forinti, a rashod 98:30. Ukupan godišnji deficit iznosi 39:44 forinti (fol. 2r).

- Govori se o najmu kuće za školskoga učitelja (ime mu se ne navodi). Kuća u kojoj učitelj stanuje već šest godina u derutnu je stanju i treba je popraviti (12. 10. 1827.) (fol. 2v i 3r).

- Stanković daje uvjerenje Antoniju Pauloviću, creskom svećeniku, Osorske biskupije, kuratu kapelanije svetoga Petra u Šajinima, da dobro obavlja svoju dužnost (4. 4. 1828.) (fol. 6v).

- Stanković moli Biskupski ordinarijat u Puli da odobri don Franji Volariću iz Vrbnika, zaređenom za svećenika prošloga Uskrsa, barbanskom učitelju (maestro pubblico di questa comune), hvaleći njegovu revnost da svaki slobodan trenutak služi kolegijalnoj (župnoj) crkvi, da smije ispovijedati. On osobno jamči za njega (Br. 28 od 23. 5. 1828.) (fol. 21r).

- Stanković Volariću daje uvjerenje da izvrsno obavlja svoju službu učitelja u barbanskoj školi i svima ga preporuča. Iz uvjerenja se vidi da Volarić pripada Senjskoj biskupiji (Br. 65 od X. Kalenda listopada 1828. ${ }^{12}$ ).

- Na temelju dekreta Ordinarijata br. 574 od 29. rujna Stanković šalje Vodnjanskom dekanatu broj zakonite i izvanbračne djece rođene od 1817. do 1828: zakonite 908, izvanbračne 26. Izvanbračne se djece nije rodilo samo 1817. i 1824., a najviše /petero/ rođeno je 1826. (Br. 42 od 13. 10. 1828.) (fol. 27v).

- Stanković daje odlične karakteristike učitelju Pietru Paolu Ragusinu iz Veloga Lošinja (Br. 84 od 29. 9. 1829.) (fol. 35r).

- Često nailazimo na razna skupljanja milostinje, posebno zbog požara u kućama u raznim krajevima.

- Stanković 1833. godine Ordinarijatu šalje izvješće o broju stanovnika:

$\begin{array}{lrr}\text { Barban i suburbij imaju ukupno } & 498 & \text { stanovnika } \\ \text { Prnjani sa zaseocima (ville) } & 1283 & \end{array}$

Šajini sa zaseocima 389

Gospa od Zdravlja sa zaseocima 306

Ukupno: 2476 (Br. 428 od 5. 12. 1833.) (fol. 127r).

- Stanković, uz ostalo, piše Kotarskom komesarijatu u Vodnjanu da je barbanska škola osnovana s preciznim uvjetom da učitelj bude crkvena osoba (Qui in Barbaana la scuola è stata eretta colla precisa condizione che vi sia un'ecclesiastico per maestro.). Navodi također da se i učenici i roditelji protive da učitelj bude svjetovnjak (... e tanto essi che $i$ genitori sono ripugnanti ad un maestro secolare.) (Br. 436 od 30. 12. 1833.) (fol. 130r).

- Osim Barbana, svoja groblja imaju i tri kapelanije. Predlaže se da se svi pokojnici pokapaju na barbanskom groblju (24. 7. 1837.) (fol. 209r).

12 Prema rimskom računanju radi se o datumu 22. rujna. 
- Podatci o stanovništvu za 1837.:

$\begin{array}{lrll}\text { Barban i suburbij imaju ukupno } & 667 & \text { stanovnika } \\ \text { Prnjani sa zaseocima (ville) } & 1174 & \\ \text { Šajini sa zaseocima } & 397 & \\ \text { Gospa od Zdravlja sa zaseocima } & 372 & \\ \quad \text { Ukupno: } & 2610 & \text { (Br. } 859 \text { od 24. 11. 1837.) (fol. 213v). }\end{array}$

- Stanković navodi da ga je nakon višekratnih zamolbi porečki i pulski biskup dekretom od 5. lipnja oslobodio dužnosti i kanonika Sebastijana Trampuša imenovao njegovim nasljednikom (Barbana 15 - Giugno - 1838. Oggi ho cessato di funzionare come vice arciprete, essendo stato esonerato dall'illustrissimo reverendissimo monsignor vescovo di Parenzo e Pola, dietro replicate mie istanze col decreto 5 giugno 1838 - $n$. 387, e fu sostituito il signor canonico don Sebastiano Trampus.) (15. 6. 1838.) (fol. 223r).

- Istoga je dana Stanković predao knjigu svom nasljedniku (Barbana - 15. Giugno - 1838. Il presente comprende carte 223 di numeri progressivi di lettere officiali N 915 consegnato al signor canonico Trampus amministratore parocchiale. - Barban - 15. lipnja 1838. Ova (knjiga) sadrži 223 lista s 915 službenih pisama (označenim) progresivnim brojevima, predana gospodinu kanoniku Trampušu) (15. 6. 1838.) (fol. 223v).

Činjenica je, međutim, da Trampuša ne nalazimo u matičnim knjigama kao arcipreta, odnosno župnika, nego kanonika Antonija Gambina.

\section{Matične knjige}

Važan izvor za povijest Barbana jesu i matične knjige. U njima nalazimo brojne vrijedne podatke. Barbanske su matične knjige dobro sačuvane. Knjige krštenih sežu u 1629., vjenčanih u 1669., a umrlih u 1691. godinu. Sačuvane su i knjige Stanja duša od 1789. godine naovamo. ${ }^{13}$

Primjerice, u Matičnoj knjizi krštenih (1716. - 1750.) osim što nalazimo ime orguljaša iz 1716., što je vrlo važno za proučavanje povijesti orguljaštva u Istri, nalazimo i ime »meštra orgulja« (Maestro d'Organi), ma što to značilo. Evo upisa:

Adi 15 Ottobre 1716

Ho Battezzato io Francesco Francovich Signor Canonico dell'Insigne Collegiata d'Albona de licenza Parrochi, un figlio maschio di Signor Antonio Manzoni Organista di questa Collegiata di Barbana, al qual hò posto il nome di Antonio nato il primo del corrente alle 2 della Notte procreatao di leggitimo matrimonio con donna Zuannetta sua

13 O povijesti vođenja matičnih knjiga vidi: Dražen VLAHOV - Jakov JELINČIĆ - Danijela DOBLANOVIĆ, »Uvod«, Vjesnik istarskog arhiva, sv. 11-13 (2004. - 2006.), Pazin, 2008., str. 11-28 (i navedenoj literaturi), a Popis barbanskih matičnih knjiga: Jakov JELINČIĆ - Branka POROPAT Danijela DOBLANOVIĆ, »Popis matičnih knjiga«, isto, str. 33-37 i JELINČIĆ, »Matične knjige župe Barban...«, str. 77-79. 
legitima Consorte. Patrini furono al Sagro Fonte il Signor Giovanni Battista Rener Maestro d'Organi e Donna Giacoma moglie di Zuanne Zelesco. ${ }^{14}$

(Dana 15. listopada 1716.

Krstih ja, Franjo Franković, gospodin kanonik časne labinske kolegijalne crkve, odobrenjem župnika, jedno muško dijete gospodina Antuna Manzonija, orguljaša ove barbanske kolegijalne crkve, kojem sam dao ime Antun, rođen (je) prvoga tekućeg (mjeseca) noću oko 2 sata, začet u zakonitu braku s gospođom Zanetom, svojom zakonitom suprugom. Kumovi bijahu pri krsnom zdencu gospodin Ivan Krstitelj Rener, meštar orgulja, i gospođa Jakova, žena Ivana Želeska.)

Svojevrsnu zanimljivost pružaju, uz ostalo, još neki upisi u ovoj knjizi. Naime, u nekoliko se navrata kao kuma na krštenju spominje Ivana, kći pokojnoga Tome Pazinjana (Pazignan). ${ }^{15}$ Prezime (ili nadimak) ukazuje na naziv grada Pazina. Nije, naprimjer, rečeno Pisinese (kao npr. Veronese, Basanese, Rovignese ...) što ukazuje na činjenicu da je pokojni Toma bio podrijetlom 'da Pazin' - Pazinjan i da je naziv Pazin bio u uporabi.

Čini se da je 1722. napravljena nova krstionica jer se u upisu krštenja Jurja, sina Jure Jeličića i žene mu Katarine, navodi da je bio prvi koji je kršten iz novoga krsnog zdenca (... battezzato fù primo al Fonte Novo) (7. 4. 1722., fol. 41r). Možda na to upućuje i podatak iz Inventara iz 1750. godine gdje se spominje:

Il Battisterio con sua conca di rame nova, salarieta d'Argento con coperchio, e Cazzetta d'Argento per battezzare $n .^{\circ} 1$

(Krstionica s novim mjedenim koritom, sa srebrenom posudicom za sol s poklopcem i srebrenom posudicom za krštavanje 1 kom.). ${ }^{16}$

U ranijim razdobljima, jer župnici uglavnom nisu vodili župnu kroniku, a i zbog skupoće papira, često su u maticama unosili bilješke o raznim događajima (gradnja ili popravak crkve, zvonika, podatke o nevremenu ili drugim elementarnim nepogodama i sl.). Tako i u Matičnoj knjizi krštenih (1781. - 1815.), na recto strani predlista, nalazimo sljedeće napomene:

\section{Adi 13 maggio 1795}

Oggi la terza giornata delle Rogazioni solito visitar la Cappella di Santa Elena e siccome alquanto scoperta di tetto la Chiesa stessa per ordine dell'Illustrissimo Signor Conte Dellegato de Bocchina hò levato le Sacre Reliquie, e la Pietra Sacra da detta chiesa avendo datto l'ordine al Campanaro Ive Spada di trasportar la Palla dell'Altare stesso, lo che esegui il dì 27 di questo mese e ressa la chiesa sospessa da se medesima. Così Io Matteo Adamich Canonico, Arciprete ad memoriam perenem.

(Dana 13. svibnja 1795.

\footnotetext{
Matična knjiga krštenih (dalje: MKK), 1716. - 1750., fol. 5r.

Npr. 4. 8. 1720. (fol. 30r), 21. 3. (fol. 34r) i 18. 7. 1721. (fol. 36r).

16 Vidi: Prilog II. - »Inventar crkvenog namještaja i liturgijskog ruha«.
}

\section{8}


Danas, trećega prosnog dana, po običaju sam posjetio kapelu svete Jelene, i budući da je na istoj crkvi ponešto otkriven krov, prema naredbi prejasnoga gospodina grofa izaslanika De Bocchine, uklonio sam iz rečene crkve svete relikvije i sveti kamen ${ }^{17}$ i naredio sam zvonaru Ivi Špadi da prenese palu s istoga oltara, što je on učinio dana 27. ovoga mjeseca i crkva je sama po sebi stavljena izvan uporabe. Tako ja, Mate Adamić, kanonik i arcipret, (napisah) na vječni spomen.)

\section{Adi 20 Aprile 1799.}

Fù ristaurata la sudeta chiesa e riposta la Pala con le Sante reliquie da me Paulo Grabar canonico seniore e Vice Parocho.

(Dana 20. travnja 1799.

Bila je obnovljena navedena crkva, a ja, Pavao Grabar, kanonik senior i zamjenik župnika, ponovno sam stavio palu i svete relikvije.)

L'Illustrissimo e Reverendissimo Monsignor Abbate Infolato Vicario Generale Capitolare di Pola Dottor Francesco Saverio Luzzich Canonico di Zagabria oggi due /2/ del Mese di Giugno mille ottocento diecisette /1817/. Benedi e Reconciliò la Chiesa della Beata Vergine di Pessaco detta Madonna della Neve.

Io Don Martino Battel Canonico, Imperial Regio Parroco ed Arciprete scrissi Pro memoria.

Arciprete

Battel

(Presvijetli i prečasni gospodin doktor Franjo Ksaver Lučić, monsinjor, mitronosni opat, pulski generalni i kapitularni vikar, kanonik zagrebački, blagoslovio je i ponovno stavio u uporabu, danas, 2. lipnja 1817. crkvu Blažene Djevice od Pesaka zvanu Gospa od Snijega.

Ja, don Martin Batel, kanonik, carsko kraljevski župnik i arcipret zapisah na spomen.

Arcipret

Batel)

Na kraju Matične knjige umrlih, vođene od 1786. do 1827. (Libro de funerali ossia de morti dell'insigne colleggiata parrochiale arcipretale di Barbana dall'anno 1786. fino all'anno 1827. secondo il Rituale Romano), nalazimo upis smrti župnika Martina Batela. Kanonik Petar Stanković, novoimenovani vicearcipret, ovako je formulirao upis činjenice smrti svog pretšasnika:

17 Radi se o četverokutnom kamenu u koji su umetnute relikvije i bez kojega se, ako one već nisu bile ugrađene u oltaru, nije smjelo misiti. 
Li 30. Agosto 1827. morto, e li 31. detto sepolto

Il Reverendissimo Signor Don Martino Battel Canonico, Parroco, ed Arciprete meritissimo di quest'insigne Collegiata Chiesa Arcipretale di San Nicolò di Barbana, d'Anni 73. passò al godimento degli eterni riposi, munito prima del Sacramento della Penitenza, ed assistenza in extremis dal Signor Canonico Pietro Stancovich, fù sepolto nel Cimitero della Chiesa filiale della B. M. V. della Porgnana, accompagnato da Barbana fino alla Sepoltura dal molto reverendo Sacerdote Don Rocco Verbich cappellano della premessa Chiesa filiale - per Stancovich.

(30. kolovoza 1827. umro, a 31. navedenoga pokopan

prečasni gospodin don Martin Batel, vrlo zaslužan župnik i arcipret ove časne arcipretne kolegijalne crkve svetoga Nikole u Barbanu, 73 godine, prešao je u uživanje vječnoga počinka nakon što je okrijepljen sakramentom ispovijedi i praćen u smrtnoj borbi od gospodina kanonika Petra Stankovića; bi pokopan na groblju filijalne crkve Blažene Djevice Marije u Prnjanima, praćen od Barbana do groba od velečasnoga svećenika don Roka Verbića, kapelana navedene filijalne crkve - umjesto Stankovića.)

\section{Neki upisi o umrlim svećenicima}

Upis smrti kanonika i arcipreta don Tome Rajka:

Adi 22. Gennaro 1766

Passò da questa alla miglior vita il quondam Don Tommaso Raico d'anni 62 circa, il quale fü intitolato con il decoroso titolo primo Arciprete in questa Collegiata in sin dell'anno 1758 dal Monsignor Giovanni Antonio Balbi Vescovo di Pola in occasione della Sacra Pastorale Visita (olim Plebanus tantum) Fù premunito de Santissimi Sacramenti, ed assistito in Agone da me Don Luca Adamich Canonico, et fù sepolto in domo, ove si sepeliscono li Sacerdoti, ed accompagnato alla Ecclesiastica Sepoltura dà tutto il Reverendo Capitolo, ed di altri Religiosi della Sacra Congrega. ${ }^{18}$

(Dana 22. siječnja 1766.

Prešao je u bolji život pokojni don Toma Rajko, star oko 62 godine, koji je bio imenovan časnim naslovom prvoga arcipreta u ovoj kolegijanoj (crkvi) od 1758. godine od monsinjora Ivana Antuna Balbija, pulskoga biskupa, prigodom njegove svete pastoralne vizitacije (nekoć /je bio/ samo župnik). Bio je okrijepljen presvetim sakramentima i praćen u smrtnoj borbi od mene, don Luke Adamića, kanonika, i bi pokopan u župnoj crkvi gdje se pokapaju svećenici i praćen do crkvenoga groba od cijelog časnog kaptola i ostalih svećenika ovoga svetog zbora.)

Upis smrti kanonika don Dominika Bianconija:

Adi 27 Marzo 1766

18 Matična knjiga umrlih (dalje: MKU), 1751. - 1815., fol. 63r (6. upis). 
Passò da questa all'altra miglior vita il Signor Don Domenico Bianconi Canonico della Collegiata di Barbana di anni 72 circa. Fù premonito dai Sacramenti della confessione e Communione, e senza Oglio Santo per un accidente all'improviso sopravenutogli, e senza assistenza. Fù sepolto nell'Archa delli Signori Quintavale, cosi avendo prima di morire ordinato situata nella Cattedrale di Caorle all'Altar di Santa Lucia col solito onorario di Lire 6 alla Pieve. ${ }^{19}$

(Dana 27. ožujka 1766.

Prešao je iz ovoga u drugi bolji život gospodin don Dominik Bianconi, kanonik kolegijalne crkve u Barbanu, star oko 72 godine. Bio je okrijepljen sakramentima ispovijedi i pričesti, a bez svetoga ulja zbog toga što mu je naglo pozlilo, i bez prisustva (svećenika) na smrtnom času. Pokopan je u grobnici gospode Quintavale, smještenoj u katedrali u Caorlama, uz oltar svete Lucije jer je tako odredio prije smrti, uz uobičajen novčani honorar župi od šest lira.)

Upis smrti kanonika i arcipreta don Petra Kolića:

Adi 22 Gennaro 1773

Passò da questa alla miglior (!) il quondam Signor Don Pietro Collich Canonico ed Arciprete di questa Chiesa Collegiata d'anni 39 circa. Fù premunito degli Santissimi Sacramenti ed assistito in agonia, non che, impartitagli l'Assoluzione in Articolo mortis per l'impotenza del Signor Canonico Seniore, dal Signor Canonico Don Nicolo Collich Costre, fù sepolto in domo nell 'arca solita de sacerdoti, ed accompagnato a quella da tutto il Capitolo, e clero di questa Congrega. ${ }^{20}$

(Dana 22. siječnja 1773.

Prešao je iz ovoga u bolji (život) pokojni gospodin don Petar Kolić, župnik i arcipret ove kolegijalne crkve, star oko 39 godina. Bio je okrijepljen presvetim sakramentima i praćen u smrtnoj borbi od gospodina kanonika seniora don Nikole Kolića Koštre, koji mu je podijelio odrješenje u smrtnom času, i bi pokopan u uobičajenoj svećeničkoj grobnici, i praćen do iste od cijeloga kaptola i klera ove svete udruge.)

Upis smrti arcipreta Mate Adamića:

30 detto ( $t j$. marzo 1799)

Reverendissimo Arciprete Don Mattio Adamich d'Anni 60 circa munito de Santissimi Sacramenti passò all'altra vitta fù sepolto capitolarmente all'Oranizza. ${ }^{21}$

(30. ožujka 1799.

Prečasni arcipret don Mate Adamić, star oko 60 godina, okrijepljen presvetim sakramentima, prešao je u drugi život (i) bio pokopan »kaptolski« na Oranici.)

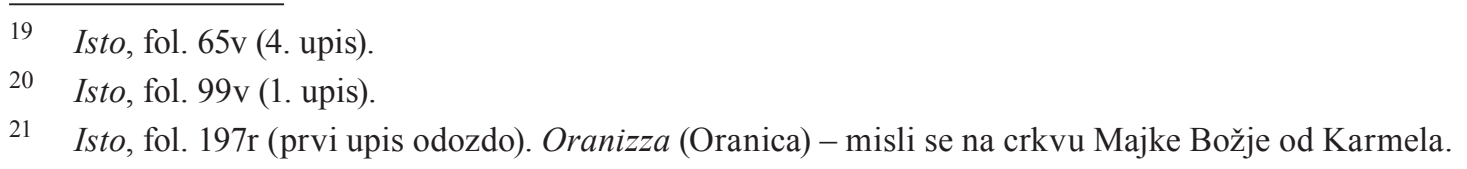


Pozornim iščitavanjem nailazimo na upise smrti nekih poznatijih osoba iz navedenoga razdoblja. Tako, primjerice, nailazimo na upis smrti pl. gosp. Bernarda Bichiacchija, sina pok. Domenika, iz Rovinja, nekoć bilježnika (ex notajo) /72 god./.22

Dovršivši Matičnu knjigu umrlih (1786. - 1827.), Petar Stanković je 26. 12. 1827. započeo vođenje nove knjige. Ovu je knjigu Stanković vodio na specifičan način, na kakav nisam naišao u četrdesetogodišnjem izučavanju matičnih knjiga. Od 13. veljače 1830. do kraja svoje službe uz upis umrloga pisao je koga je sve pokojnik ostavio iza sebe, a za velik dio ostavljenih nasljednika pisao je i točan datum rođenja. Isto je nastavio i Trampuš, kao i kanonik Antonio Gambin koji je 1. studenog 1838. imenovan župnikom.

\section{POZNATI BARBANAC PETAR STANKOVIĆ (Pietro Stancovich)}

Nemoguće je govoriti o Barbanu, a ne spomenuti kanonika i znanstvenika Petra Stankovića. Mislim da bi također rad o barbanskom kaptolu i župi, a da se ništa ne kaže o najpoznatijem barbanskom kanoniku, bio manjkav. ${ }^{23}$

Njegova pojava i njegov rad obilježili su ne samo vrijeme njegova života nego i povijest Barbana poslije njega, a obilježavat će ga i dalje, posebno zahvaljujući godišnjem znanstvenom skupu »Barban i Barbanština od prapovijesti do danas«, koji će uvijek djelomice biti posvećen Stankovićevu životu i radu.

22 MKU (Liber defunctorum 1821. - 1841.), str. 41 (sedmi upis).

23 Stanković je postao kanonikom svega dvije godine nakon ređenja. Naime, razlikuju se podatci o godini kada je postao kanonikom. Jedni tvrde da je kanonikom postao 1797., a drugi govore o 1798. godini. Nema sumnje da je titulu kanonika imao krajem 1797. što je vidljivo, uz ostalo, u MKU 1751. - 1815. (spominje se kao kanonik barem od 17. listopada 1797.; riječ je o upisu smrti Foške, udovice pok. Tome Ivanušića. Pogreb je vodio kanonik Pavao Grabar umjesto kanonika Stankovića; bez fol.). O tako ranom stjecanju kanonikata Petar Strčić piše: »Kao sin mjesnog bogataša, a usto zaista nadaren, Stanković je lako bio izabran čak i za kanonika, prije uobičajenih rokova, i to još kao sasvim mlad čovjek; no stekavši kanoničku čast, nije mario za to da se bavi za njega dosadnim pastoralnim obavezama što ih je sa sobom nosila svakidašnja, obična plovanska služba...«(Petar STRČIĆ, Petar Stanković, život i djelo, ZN »Žakan Juri«, Pula, 2011., str. 9.) Što se tiče činjenice da je Stanković već nakon dvije godine postao kanonikom, mislim da tu nema mjesta čuđenju jer je bilo slučajeva da su neki klerici i prije primanja viših redova, barem u 18. st., imali kanonikat, a ranije su i laici mogli biti kanonici (npr. Nikola Kopernik). U Knjizi ređenja Pićanske biskupije od 1632. do 1783. (Prothocollum illustrissimi atque reverendissimi in Christo domini domini Gaspari Bobegh Dei et Apostolicae Sedis Gratia Episcopi Petenensis ... Anno Salutis Nostrae 1632), u koju su ređenja nastavili pisati nasljednici Gašpara Bobeka na pićanskoj biskupskoj stolici, sve do posljednjega u nizu pićanskih biskupa Aldraga Antonija de Picardija, koji je posljednje ređenje obavio 2. studenog 1783. (usp. Jakov JELINČIĆ, Knjiga ređenja u Pićnu (Prothocollum) (1632. - 1783.), Posebna izdanja, sv. 17, Državni arhiv u Pazinu, Pazin, 2015., str. 258 / fol. 124v), također nalazimo slučaj da je nekoliko kanonika zaređeno za svećenike, a neki su već kao »kanonici« primili i sve ostale niže i više redove. Tako je pićanski biskup Paulus de Tauris 30. svibnja 1665. u pićanskoj katedrali Uznesenja Marijina zaredio za subđakona, 19. rujna za đakona, a 19. prosinca iste godine za svećenika, Alojzija Corsina, kanonika porečkoga (isto, str. 65-67 / fol. 32v, 33r i 34v). Isti je biskup 1665. godine podijelio dva niža reda, subđakonat i đakonat, porečkom kanoniku Mateju Paliagi iz Rovinja (isto, str. 64-66 / fol. 32r, 32v i 33r). Josipa Mihovila Loschija, kanonika brsečkog, isti je biskup zaredio za đakona 30. ožujka 1675., a za svećenika 8. lipnja iste godine (isto, str. 81-82 / fol. 45v i 46r). Biskup Ivan Josip Bonifacije de Ceccotti zaredio je za đakona 13. ožujka 1745. Antuna Ruščića, kanonika lovranskog (isto, str. 137 / fol. 65v). Dana 18. rujna 1779. biskup Antun Aldrago de Picardis za svećenika je zaredio riječkoga kanonika Nikolu Tudorovića (isto, str. 249 / fol. 118v). 
O Stankoviću se puno pisalo, međutim, čini se da se kod nekih autora premalo naglašava Stankovićeva duhovna dimenzija premda je on prije svega bio - svećenik. Čini mi se, naime, da se o nekim stvarima piše previše paušalno, bez navođenja izvora.

Treba reći da o Stankoviću postoji bogata literatura. ${ }^{24}$

Smatram potrebnim, kada već govorimo o izvornom gradivu, navesti ovdje podatke o obitelji Stanković do kojih sam uspio doći listajući neke od matičnih knjiga, ali i upozoriti na činjenicu da bi se pomnijim proučavanjem spisâ, koji još čekaju detaljno sređivanje, dobila cjelovitija slika Stankovićeva pastoralnoga rada, što je vidljivo iz navedenoga Registra pisama.

Iz onoga što sam dosad ustanovio, vidljivo je da je Stanković vrlo savjesno obavljao službu i kanonika i v. d. župnika. ${ }^{25}$

Napominjem da sam temeljito pregledao upise krštenja djece Antuna i Notburge Stanković, detaljno sam pregledao knjige umrlih kako bih našao podatak o smrti Antunove druge supruge Franceske, kao i knjigu umrlih kako bih ustanovio kada je umro navodni izvanbračni sin Ivan II. Pregledao sam i notirao sve upise krštenja djece Antunove kćeri Andrijane i njena supruga Alessandra d'Ellettija. Ustanovio sam, dakle, sljedeće:

Antun Stanković rodio se 1747.:

Adi 20 detto (tj. maggio) 1747.

Mattio ${ }^{26}$ Antonio figlio del Signor Martin Stancovich, et di Andrian (!) sua legitima consorte, nato li 16 detto. Padrini furono il Signor Antonio Orbasio et Giovanna relita del

24 Vidi: STRČIĆ, Petar Stanković..., str. 35 i 52-59.

25 Pitanje vrlo ranoga stjecanja kanonikata Strčić spominje i kasnije. U nastavku navedenoga teksta kaže da se Stanković »bavio onim poslovima koji su mu ležali: bio je dugi niz godina administrator župe, dakle bavio se problemima koji su bili vezani uz gospodarsku praksu, uz novac, a to mu je očito "ležalo" u naravi« (isto, str. 96). Treba također naglasiti da položaj upravitelja župe (administratora) nije obuhvaćao samo administriranje - upravljanje crkvenom imovinom. Administrator obavlja funkciju župnika i ima njegove obveze i prava, s tom razlikom što stalnog - imovibilnog župnika biskup nije mogao premjestiti bez njegova pristanka, a upravitelja je župe mogao. Što se pak tiče tvrdnje da Stanković nije mario za obveze koje proizlaze iz pastoralne službe, to jednostavno ne može biti, i to iz razloga što je svaki kanonik imao određene obveze u određenim danima, i to je bio izvor kanoničkih prihoda. Iz upisa u matičnim knjigama vidljivo je da je i Stanković, kao i ostali kanonici, krštavao, vjenčavao i pokapao. Posebno je nezgodna i upitna ova Strčićeva formulacija: »Stankovića je očeva ruka gurnula među svećenike a ne, kao mlađu braću, među liječnike i pravnike, ili pak među tehničare i trgovce, kamo je očito pripadao. No kad je već morao postati i postao svećenik, poslužio se višestrukim prednostima svoga crkvenog zvanja, ne držeći mnogo ni do vjere ni do Katoličke crkve, niti do svojih vjernika, našavši načina da ih iskoristi u osobne svrhe« (isto, str. 95). Ne ulazeći u pitanje koje su to bile (očito materijalne) prednosti crkvenoga zvanja (a znamo iz povijesti Barbanu susjedne male Pićanske biskupije da su svećenici i kopali kako bi preživjeli i često nisu imali novaca da bi kupili doličnu svećeničku odjeću), ovdje ipak moramo podsjetiti na staru pravnu postavku da sudac ne može suditi o onome što se nalazi u čovječjoj savjesti (De internis non iudicat praetor). Teško bi bilo reći i za najobičnijeg (uvjetno rečeno) vjernika da ne drži do vjere i Katoličke Crkve, a posebno se to čini presmionim reći za svećenika.

26 Činjenica je da u matičnim knjigama često dolazi do zbrke jer se miješaju imena Matija i Matej (lat. Mathias i Mathaeus, tal. Mattia, Mattio i Matteo). Prihvaćam oblik Matija, koji je uobičajen za kanonika Matiju Petra Stankovića. 
Signor Zorzi Ghogorovich (!) et de Pre Vicenzo Tonich fu battezato de Licenzia Parrochi (fol. 176v).

(Dana 20. tekućeg (tj. svibnja) 1747.

Matija Antun, sin gospodina Martina Stankovića i Andrijane, njegove zakonite supruge, rođen 16. navedenog. Kumovi bijahu gospodin Antun Orbasio i Ivanka udova gospodina Jurja Gogorovića (!) i od svećenika Vicka Tonića bi kršten župnikovim odobrenjem).

Pregledom Matičnih knjiga krštenih (1750. - 1781. i 1781. - 1816.) pronašao sam upise krštenja desetero djece. Prema upisu Notburgine smrti 1782., ona je tada imala oko 30 godina, što znači da je pri prvom porodu, 1767., imala oko 15 godina. Za Antuna znamo da je 16. 5. 1747. rođen. Imao je pri prvom porodu supruge Notburge nepunih 20 godina. ${ }^{27} \mathrm{Iz}$ upisa krštenja prvoga djeteta, ali i iz upisa Antunove smrti, kao i iz upisa Notburgine smrti, vidljivo je, dakle, da su se vjenčali vrlo mladi. ${ }^{28}$

\section{Upisi krštenja djece bračnoga para Antuna i Notburge Stanković}

Vrlo sam detaljno pregledao upise krštenih u Matičnoj knjizi krštenih 1750. - 1781. i u onoj od 1781. do 1815. te našao upise krštenja sljedeće Antunove i Notburgine djece:

U MKK (1750. - 1781.):

Andreana Maria ${ }^{29}$ rođena 17., krštena 19. ožujka 1767. (fol. 76v)

Petrus Martinus, kršten 17. ožujka 1769. (fol. 90v) ${ }^{30}$

Pietro Mattio, rođen 22., kršten 24. veljače 1771. (fol. 99v)

Vicenzo Mattio, rođen 22., kršten 27. siječnja 1773. (fol. 109r)

Mattio Antonio, rođen 4., kršten 9. rujna 1775. (fol. 121v)

Zuanne, rođen, kršten u kući i odmah umro 7. rujna 1776. (fol. 126r)

Anna Maria Santa, rođena 2., krštena 3. studenoga 1777. (fol. 133v)

Cattarina Anna, rođena 22., krštena 27. studenoga 1779. (fol. 146v)

U MKK (1781. - 1816.):

Zuanne, rođen, kršten u kući i odmah umro, 14. listopada $1781 .^{31}$

27 Strčić, citirajući druge autore, navodi da je Martin Stanković imao trinaestero djece (od toga jednoga, Ivana II. izvanbračno); STRČIĆ, Petar Stanković..., str. 62; bilj. 107, str. 135.

28 Budući da nisam našao upis vjenčanja, zaključujem da se, što je i uobičajeno, vjenčao u župi svoje zaručnice Notburge - Gračišću. Pokušao sam pomoću zapisa na CD-u ustanoviti kada se to vjenčanje dogodilo, no kako je tekst dosta loš, nisam uspio doći do rezultata. Budući da Gračišće nema stalnoga župnika, nisam u mogućnosti pregledati knjigu in situ, no to kanim učiniti čim mi se pruži prigoda.

Navodim imena kao u izvornim upisima.

30 Ne navodi se datum rođenja. Krštenje obavio gračaški nadžupnik Franjo Ignacije (prezime se ne navodi); MKK 1750. - 1781., fol. 90v (prvi upis).

31 MKK 1781. - 1816., fol. 2r (treći upis odozdo). 
Zuanna, rođena, krštena u kući i odmah umrla, kao i majka, 29. listopada 1782.32

Posebno navodim upis krštenja Petra Stankovića:

Adi 24 Febbraio 1771

Pietro Mattio Figlio del Signor Antonio Stancovich del Signor Martin e della Signora Notburga nata Martinich da Gallignana giugali, naque li 22 corrente. Fù battizato dal Signor Arciprete Pietro Collich. Padrini furono il Molto Illustre Signor Francesco Capponi e Maria moglie di Gasparo de Franceschi da San Vincenti. ${ }^{33}$

(Dana 24. veljače 1771.

Petar Matija, sin gospodina Antuna Stankovića, (sina) gospodina Martina, i gospođe Notburge rođene Martinić iz Gračišća, supružnika, rođen 22. tekućega (mjeseca). Bio je kršten od gospodina arcipreta Petra Kolića. Kumovi bijahu presvijetli gospodin Francesko Capponi i Marija, žena Gašpara de Franceschija iz Svetvinčenta.).

U literaturi se navodi da su Antun i Notburga imali dvanaestoro djece što je teško za pretpostaviti jer je Notburga pri prvom porodu imala vjerojatno nešto više od 15/16 godina, a Antun nešto manje od 20. Za ostalo dvoje djece koje bi bilo rođeno nema podataka u matičnim knjigama krštenih, a uspoređujući ritam rađanja, gotovo da se »za njih i ne bi moglo naći mjesta«.

Notburga je umrla vrlo mlada. Evo upisa smrti:

Adi 30 Ottobre 1782.

La Signora Notburga fù moglie del Signor Antonio Stancovich di anni 30 circa passò da questa al altra miglior vita, premunita de Santissimi Sacramenti con assistenza finale dal Signor Currato don Matteo Adamich, e fu sepolta qui in Domo, accompagnata alla sepoltura dal Signor Canonico Steffano Raico. ${ }^{34}$

32 Isto, fol. 6v (treći upis odozdo). Pitanje je je li uopće rođena živa. Krštena je, naime, uvjetno (sub conditione) jer župnik nije bio siguran je li dijete živo. Strčić o Stankovićevu brojnom potomstvu piše: »... što zakonitom, što nezakonitom...«, no spominje se samo izvanbračni sin Ivan II. Istražujući podatke o izvanbračnoj djeci, naišao sam samo na jednoga Ivana kojega je rodila izvjesna Marija iz Čepića. Marijino se prezime ne spominje, a upis glasi: Adi 9 Giugno 1786 - Zuanne figlio di Maria Foresta da Cepich e di padre incognito naque gieri e fù Battezato dal Signor Canonico Paulo Grabar de Licenza parochi. Padrini furono il Signor Dottor Pietro Vituri medico e la Signora Francesca relita Simon Zadro nata Stancovich. (fol. 19r) - (Dana 9. lipnja 1786. - Ivan, sin Marije, strankinje iz Čepića, i nepoznata oca, rođen jučer i bi kršten od gospodina kanonika Pavla Grabara župnikovim odobrenjem. Kumovi bijahu gospodin doktor Petar Vituri i gospođa Frančeška udovica Šimuna Zadra, rođena Stanković.) Na eventualno Antunovo očinstvo moglo bi upućivati kumstvo Franceske Zadro, rođene Stanković, međutim, nju često nalazimo kao kumu na krštenju. No, treba reći da se u matičnoj knjizi umrlih ne nalazi upis smrti dotičnoga Ivana.

33 MKK 1750. - 1781., fol. 99v (prvi upis).

34 MKU 1751. - 1815., fol. 150r (šesti upis). 
(Dana 30. listopada 1782.

Gospođa Notburga, žena gospodina Antuna Stankovića, stara oko 30 godina, prešla je iz ovoga u drugi, bolji život, okrijepljena svim presvetim sakramentima uz pomoć u smrtnom času gospodina kurata don Mate Adamića, i bi pokopana u ovoj župnoj crkvi, praćena do groba od kanonika Stjepana Rajka.)

Kako je već navedeno, Notburga je umrla pri porodu kćeri Ivanke (Zuanna) koja je također umrla, i to svega nekoliko sati nakon rođenja. Pokopana je također u župnoj crkvi, vjerojatno zajedno s majkom. ${ }^{35}$ Pogreb je također vodio kanonik Rajko. ${ }^{36}$

Suprug Antun ponovno se vjenčao, i to u Vodnjanu, s Franceskom Damianis, kćeri pok. Damjana, te je Notburgu nadživio gotovo 28 godina:

\section{Adi 5 Agosto 1804}

Il Signor Antonio Stancovich quondam Martin da Barbana e la Signora Francesca Damianis quondam il Signor Damian di questa parrocchia dispensati dalle trine Conciliari Publicazioni con mandato della Curia de 4 corrente agosto, ricevuto il loro mutuo consenso per verba de presenti ${ }^{37}$ jeri sera sono stati congiunti in Santo Matrimonio nella Casa della sposa per speciale concessione della Curia come de Mandato precitato, da me Don Giovanni Dottor Tromba alla presenza dell'Eccellente Signor Giacinto Uganin Medico fisico e del Signor Giovanni Bagozzi, testimoni vocati e rogati, non che de molti altri presenti, tutti di questa Parrocchia, ed oggi nella chiesa della Beata Vergine del Carmine nella Santa Messa ho loro impartite le Nuziali Benedizioni.

\section{Giovanni Dottor Tromba $m p^{38}$}

(Dana 5. kolovoza 1804.

Gospodin Antun Stanković pok. Martina iz Barbana i gospođa Franceska Damianis pok. Damjana iz ove župe oslobođeni od triju koncilskih oziva odredbom Kurije od 4. tekućeg (mjeseca) kolovoza, primivši njihovu uzajamnu privolu, sinoć su združeni u svetu ženidbu u kući zaručnice na temelju posebnoga odobrenja Kurije, kao u navedenoj odredbi, od mene, don Giovannija Trombe, u nazočnosti uzvišenoga gospodina Giacinta Uganina, liječnika fizika, i gospodina Giovannija Bagozzija, svjedokâ zvanih i umoljenih, kao i mnogih drugih nazočnih, svih iz ove župe, i danas sam im u crkvi Blažene Djevice od Karmela podijelio vjenčane blagoslove.

\section{Giovanni doktor Tromba vr.) $)^{39}$}

35 Ako nije pokopana u tzv. anđeoskom (tj. dječjem) grobu.

36 MKU 1751. - 1815., fol. 150r (7. upis).

37 Izraz je vjerojatno iz crkvenoga prava, a trebao bi značiti: »po riječima prisutnih (zaručnika)« jer se vjenčanje moglo, u iznimnim slučajevima, obaviti i bez njihove nazočnosti ili nazočnosti samo jednoga zaručnika, uz nazočnost opunomoćenih (-og) zastupnika.

38 Matična knjiga vjenčanih župe Vodnjan (dalje: MKV), 1703. - 1809., fol. 250r (prvi upis odozdo).

39 Antunova djeca nisu bila zadovoljna očevim novim (nejednakim) brakom (STRČIĆ, Petar Stanković..., str. 98 i bilj. 251, str. 152). Šime JURIĆ u svom radu »Dopisivanje Petra Stankovića s braćom Appendinijima« (Anali Historijskog instituta JAZU, I, Dubrovnik, 1952., str. 418), smatra da se izraz nejednaki 
Antun je umro 1810. god. navršivši 63 godine:

28 detto (tj. maggio) 1810.

Il Signor Antonio Stancovich d'anni 67 circa $^{40}$ passò all'altra vita munito de'Santissimi Sacramenti, colla finale assistenza del Capitolo, e fu sepolto capitolarmente a Santa Croce, accompagnato in terzo dal Capitolo, unitamente ad altri tre Sacerdoti. (fol. 231r)

(28. svibnja 1810.

Gospodin Antun Stanković, star oko 67 godina, prešao je u drugi život okrijepljen presvetim sakramentima, uz asistenciju kaptola u smrtnom času, i bje pokopan »kaptolski«, praćen trojicom od kaptola i od drugih triju svećenika.)

Nikakvo čudo da je župnik napisao kako je Antun imao oko 67 godina. Neki su župnici točno u dan navodili starost umrloga, a neki s circa. Budući da znamo točan dan rođenja i da je župnik pogriješio za 4 godine, vjerojatno je pogriješio i u svezi sa starošću njegove žene Notburge. No, kako je i onda bilo uobičajeno da zaručnik bude stariji od zaručnice, smijemo pretpostaviti da je ona prigodom vjenčanja imala najviše 18 godina.

Na kraju navodim i upis o smrti kanonika Petra Stankovića:

\section{Barbana li 12 Settembre 1852}

Il Reverendissimo Signor Don Pietro Stancovich Canonico emeritissimo di questa Colleggiata e Socio di varie Accademie e d'Istituti Scientifici di questo Castello N. 46 nato li 21 (!) febbrajo 1771. passò agli eterni riposi colpito da una appoplessia con febbre perniciosa e fu sepolto nel Cimitero di Santa Croce in terzo dal Parroco Antonio Gambin Antonio Kroizer ed Antonio Ghergorinich con altri 13 (!) Sacerdoti dei limitrofi luoghi.

(45. ${ }^{41}$ Barban, 12. rujna 1852.

Prečasni gospodin don Petar Stanković, vrlo zaslužni kanonik ove kolegijalne (crkve) i član raznih akademija i znanstvenih ustanova, s br. 46 ovoga kaštela, rođen 21. (!) veljače 1771., prešao je u vječni počinak udaren od kapi s pogubnom ognjicom i bio je pokopan na groblju Svetoga Križa uz trojicu: od župnika Antuna Gambina, Antuna Kroizera i Antuna Grgorinića s ostalih 13 svećenika iz okolnih mjesta. $)^{42}$

brak odnosi ili na činjenicu da je Franceska bila premlada za Antuna Stankovića ili na to da je bila iz nižega društvenog sloja. Čini se da ovo drugo nije mogao biti uzrok jer se u upisu vjenčanja navodi izraz Signora odnosno Signor. Budući da nisam našao nikakav trag ni o Franceskinu rođenju ni o smrti, na prvo pitanje ne mogu odgovoriti. No, ako su zaista djeca bila protiv toga braka, moguće je da se, nakon Antunove smrti, vratila u Vodnjan (što nisam uspio ustanoviti) ili se, pak, (ako je bila puno mlađa od Antuna) ponovno udala. Sve se ovo, međutim, svodi na razinu pretpostavke.

Imao je 63 godine i 12 dana, a ne »oko $67 \ll$.

41 Redni broj upisa.

42 MKU 1843. - 1879. (bez oznake lista). 
U matičnim knjigama barbanske župe ima dosta upisa krštenja, vjenčanja i smrti članova obitelji Stanković. Bilo bi dobro da netko, tko ima znanja i strpljenja, istraži te podatke.

Osim već navedenih podataka ovdje navodim samo djecu najstarije kćeri Antuna i Notburge Stanković, Andreane Marije, koja se 15. travnja 1803., kao 36-godišnja djevojka udala za barbanskoga kancelara Alessandra D'Ellettija ${ }^{43}$ Prvo su dijete dobili u veljači 1804., a nakon četiri kćeri dobili su 8. svibnja 1809. jednoga sina. Alessandro D'Elletti umro je 18. 12. 1825. u dobi od 74 godine (MKU 1821. - 1841., pag. 12), a do podatka o smrti žene mu Andriane nisam uspio doći. Navodim imena te datume rođenja i krštenja njihove djece:

Cattarina Francesca Ellena, 14. 2. / 23. 2. 1804. (fol. 88v)

Francesca Giovanna Notburga, 11. 4. / 17. 4. 1805. (fol. 90r)

Maria Teresia, 7. 11. / 16. 11. 1806. (fol. 97r)

Anna Antonia Giovanna, 21. 1. 1808. (fol. 105v) $)^{44}$

Alessandro Gavardo Antonio, 8. 5. / 19. 5. 1809. (fol. 113r).

\section{ZAKLJUČAK}

Dosta sam dugo listao gradivo ovoga bogatog arhiva, no još uvijek premalo da bih dobio pravu sliku o njegovoj vrijednosti. Sređivanje crkvenih arhiva u Istri očekuje nove snage, ali i drugačije uvjete u župnim stanovima kako bi se oni mogli srediti i učiniti pristupačnim novim mladim istraživačima. Svakako treba znati da pristup crkvenim arhivima pretpostavlja poznavanje latinskoga jezika, a u Istri također i talijanskoga, u nekima i njemačkoga jezika. Potrebno je također poznavanje crkvene terminologije.

S obzirom na ulogu i značaj kanonika Petra Stankovića u povijesti Barbana na prijelazu 18. u 19. st. te s obzirom na njegov duhovni poziv kojemu se odazvao i kontroverze u historiografiji koje ne prestaju glede njegova imovnoga stanja i obitelji iz koje je potekao, odlučio sam neka od tih pitanja pojasniti koristeći podatke pronađene upravo u župnom arhivu Barbana. Stoga ističem činjenicu da se proučavanjem arhivskoga gradiva, a matičnih knjiga, rekao bih, posebno, mogu izbjeći mnoge pogreške i loše interpretacije.

\footnotetext{
$43 \quad$ MKV 1753. - 1826. (nepaginirano).

44 Ne navodi se datum rođenja.
} 


\section{PRILOG I.}

\section{Povelja o posveti crkve ${ }^{45}$}

In Christi Nomine Amen Anno Nativitatis eiusdem 1701 Indictione prima,

(U Ime Kristovo, amen. Godine od Njegova rođenja 1701., indikcije prve die Dominico VI mensis Martii Actum Barbanae in Visitatione Episcopali Sub u nedjelju šestoga dana mjeseca ožujka, sačinjeno u Barbanu prigodom biskupske

Pontificatu Illustrissimi Domini Nostri Domini Domini Clementis Papae XI

vizitacije, u prvoj godini pontifikata prejasnoga gospodina našega gospodina gospodina Anno primo. Presentibus Admodum Reverendissimo Don Liberale Vio

Klementa pape XI., u prisustvu prečasnoga gospodina don Liberala Vija, Canonico Ecclesiae Cathedralis Polensis ac Reverendo Bartolomeo Baici

kanonika pulske katedralne crkve, i velečasnoga Bartolomea Baicija,

Cerimoniario eiusdem Cathedralis testibus ad haec specialiter deputatis vocatis

ceremonijara iste katedrale, u svojstvu svjedokâ za ovu prigodu određenih i pozvanih.

Notum sit omnibus, quod Illustrissimus et Reverendissimus Dominus

Neka bude znano svima da je prejasni i prečasni gospodin

Dominus Frater Joseph Maria Bottari Civis Venetus, Dei et Sanctae Sedis

gospodin fra Josip Marija Bottari, građanin venetski, milošću Božjom i Svete

Apostolicae Gratia Episcopus Polensis et Sacrae Caesareae Regiaeque

Apostolske Stolice biskup pulski i savjetnik Svetoga Carskog i Kraljevskog

Maiestatis Consiliarius humiliter requisitus à Jacobo Contich dicto Matuchina

Veličanstva, ponizno zamoljen od Jakova Kontića, rečenoga Matukina,

Suppano, Joanne Vidich alias Paulich Pozuppo actualibus, Vincentio Rossich

sadašnjega župana, Ivana Vidića, rečenoga Paulić, sadašnjega podžupana, Vincenca Rosića, Procuratore, Andrea Dragozet Michaele Colich Judicibus et

prokuratora, Andrije Dragozeta i Mihovila Kolića, sudaca

representantibus Communitatem Barbanae solemni ritu consecravit Ecclesiam

predstavnikâ barbanske općine, svečanim obredom posvetio crkvu

Sancti Nicolai huius Loci à fundamentis erectam, quae quidem ab antiquo est

svetoga Nikole ovoga mjesta, iz temelja podignutu, koja je također od davnine

Colleggiata istius Castri, et simul cum ea Altaria quinque in eadem existentia

zborna crkva istoga kaštela. Zajedno s njom posvetio je pet oltara koji se u njoj nalaze,

45 Tekst Isprave transkribiran sa svim jezičnim i pravopisnim osobitostima. 
nimirum Altare Maius Sancto Nicolao Episcopo et Confessori, in quo includit

i to glavni oltar posvećen svetom Nikoli biskupu i ispovjedaocu, u koji je umetnuo Reliquias Sanctorum Martirum Felicis, Domitiani et Eusebii. Altare Dominae relikvije svetih mučenika Feliksa, Domicijana i Euzebija, oltar Blažene Djevice Mariae Virginis Rosarii, in quo inclusit Reliquias eorundem Sanctorum

Marije od Ružarija, u koji je umetnuo relikvije istih svetih Martirum, Altare Omnium Sanctorum in quo etiam condidit ex eisdem Reliquiis, mučenika, oltar Svih svetih, u koji je također umetnuo iste relikvije, Altare Sancti Sebastiani Martiris in quo pariter reposuit de eisdem Reliquiis, et oltar svetoga Sebastijana, mučenika, u koji je također umetnuo iste relikvije, i Altare Sancti Francisci de Paula in quo inclusit Reliquias Sanctorum Martirum oltar svetoga Franje od Paole, u koji je umetnuo relikvije svetih mučenika Caii, Pii et Columbe, atque omnibus et quibuscumque Christi fidelibus dictam Kaja, Pija i Kolombe te je svima i svakom Kristovu vjerniku koji je danas Ecclesiam et Altaria hodie visitantibus centum dies Indulgentiae et in pohodio crkvu i oltare podijelio sto dana oprosta, a prigodom Anniversario huiusmodi quadraginta dies pro quolibet altari singulis annis obljetnice također četrdeset dana za [posjet] svakom oltaru concessit, et ad futurorum hoc presens Publicum Instrumentum confici te je naredio da se sačini ova javna isprava mandavit, sigiloque Curiae suae Episcopalis communiri iussit et ita i zapovjedio da se ona osnaži pečatom njegove biskupske kurije i tako.

$L S$

MP
Ioannes Baptista Corneaneus Plebanus Philipani Vice Cancellarius Avintus Ioannes Baptista Corneano, župnik Filipane, vicekancelar avintus $^{46}$.)

46 Izraz nejasan. 


\section{PRILOG II.}

U samom tekstu bilo je nekoliko pojmova koje nisam uspio razriješiti. U tome su mi pomogle prof. dr. sc. Nina Kudiš s Filozofskoga fakulteta u Rijeci te Iva Jazbec, asistentica (doktorandica) s istoga fakulteta, i doktorandica Mateja Jerman, kojima ovom prigodom srdačno zahvaljujem. No, još je uvijek ostala poneka nepoznata riječ.

Ovaj se inventar nalazi na kraju MKKr (1744. - 1826.).

\section{Inventar crkvenoga namještaja i liturgijskoga ruha}

(fol. 1r)

Adi 20 agosto 1750

(Dana 20. kolovoza 1750.

Inventario de'sacre suppelletili di ragione di quest'Veneranda

Inventar svete opreme ove časne

Chiesa di San Nicolò stabilito per ordine

crkve svetoga Nikole, sačinjen prema nalogu

e venerate Commissioni di Sua Eccellenza Signor Giovanni Loredan

i poštovanim odredbama Njegove Uzvišenosti gospodina Giovannija Loredana,

Signore e Padrone $e^{47}$ alla Presenza dell'Illustrissimo

gospodina i gospodara, u nazočnosti presvijetloga

Signor Francesco Candido Capitano G. D.,

gospodina Francesca Candida, kapetana G. D. (?)

e del Reverendissimo Signor Don Tomaso Pievano ${ }^{48}$

i prečasnoga gospodina župnika don Tome

47 Giovanni Loredan, »kavalir, Gospodin i apsolutni gospodar Barbana, Raklja i njegovih područja«, izdao je 1759. godine terminaciju u šest točaka. Cijela se terminacija odnosi na čuvanje, sređivanje i općenito brigu za kaptolski arhiv; KLEN, »Arhiv Barbana i Raklja...«, str. 342.

Radi se o župniku Tomi Rajku. Prvi se put upisuje kao pievano 26. siječnja 1738.; MKK (Liber Baptizatorum Colleggiate Sancti Nicolai Barbanae, 18. 5. 1716. do 25. 8. 1750.), fol. 135r (navodi za sebe da je izabran za plovana (elleto pievano). Kao plovan zadnji se put upisuje Jakov Ramilović 3. veljače 1737. (isto, fol. 129v). Jedno je krštenje obavljeno 21. prosinca 1737. de licenzia Parochi (isto, fol. 134r). Passò da questa a miglior vita il quondam Don Tommaso Raico d'anni 62 circa, il quale fù intitolato con il decoroso Titolo di primo Arciprete in questa Colleggiata in sin dall'anno 1758 dal Monsignor Giovanni Andrea Balbi Vescovo di Pola in occasione della Sacra Pastorale Visita (olim Plebanus tantum) Fù premunito de Santissimi Sacramenti, ed assistito in Agone da me Don Luca Adamich Canonico, et fù sepolto in Domo, ove si sepeliscono li Sacerdoti, ed accompagnato alla Ecclesiastica Sepoltura dà tutto il Reverendo Capitolo, ed di altri Religiosi della Sacra Congrega; MKK 1751. - 1815., fol. 63r. 
quali si ritrovano in esser sino al giorno d'oggi

koja se [sveta oprema] nalazi do današnjega dana

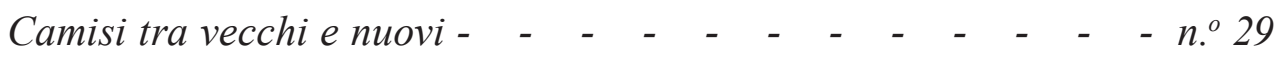

Misne košulje, što stare, što nove 29 kom.

Camisi novi per le Solenità - $\quad$ - $\quad$ - $\quad$ - $\quad$ - $\quad$ - $\quad$ - $\quad$ - $\quad$ - $\quad$ - $\quad$ - n. 3

Nove misne košulje za svečane prigode $\quad 3 \mathrm{kom}$.

Cingoli di seda verdi trà vecchi, et usati - $\quad$ - $\quad$ - $\quad$ - $\quad$ - $\quad$ - n. ${ }^{\circ} 13$

Svileni pojasevi, što stari, što rabljeni

13 kom.

Detti bianchi vecchi, et inutili - $\quad$ - $\quad$ - $\quad$ - $\quad$ - $\quad$ - $\quad$ - $\quad-n .^{\circ} 2$

$\begin{array}{ll}\text { Rečeni bijeli stari i neuporabivi } & 2 \text { kom. }\end{array}$

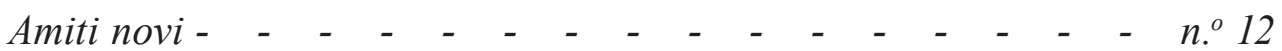

Novi naglavnici

12 kom.

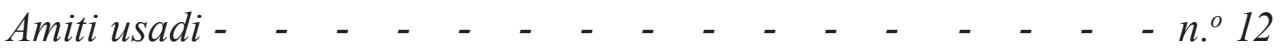

$\begin{array}{ll}\text { Rabljeni naglavnici } & 12 \text { kom. }\end{array}$

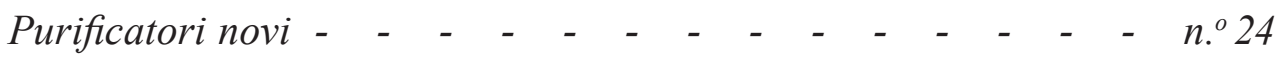

$\begin{array}{ll}\text { Novi purifikatoriji } & 24 \mathrm{kom} .\end{array}$

Detti trà vecchi, et usati - $\quad$ - $\quad$ - $\quad$ - $\quad$ - $\quad$ - $\quad$ - $\quad$ - $\quad$ - $\quad$ n. ${ }^{\circ} 10$

$\begin{array}{ll}\text { Rečeni stari i rabljeni } & 10 \text { kom. }\end{array}$

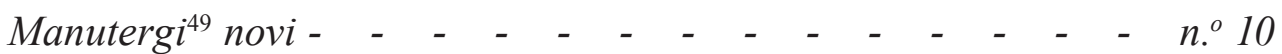

$\begin{array}{ll}\text { Novi rupčići } & 10 \mathrm{kom} .\end{array}$

Corporali vecchi - $\quad$ - $\quad$ - $\quad$ - $\quad$ - $\quad$ - $\quad$ - $\quad$ - n. ${ }^{\circ} 20$

$\begin{array}{ll}\text { Stari tjelesnici } & 20 \mathrm{kom} .\end{array}$

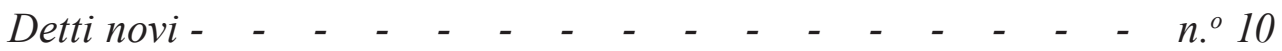

$\begin{array}{ll}\text { Novi tjelesnici } & 10 \mathrm{kom} .\end{array}$

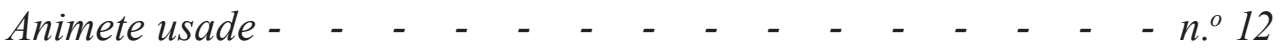

Rabljene pale [za kalež] 12 kom.

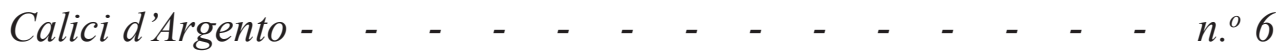

$\begin{array}{ll}\text { Srebreni kaleži } & 6 \text { kom. }\end{array}$

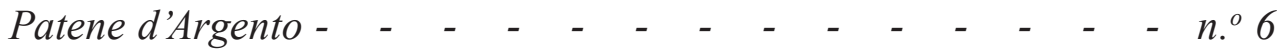

$\begin{array}{ll}\text { Srebrene patene } & 6 \mathrm{kom} . \\ \end{array}$

49 Riječ manutergium, -ii, $n$. znači ručnik, obrisač (Jozo MAREVIĆ, Latinsko-hrvatski enciklopedijski rječnik, II. svezak, Matica hrvatska - MARKA, Zagreb - Velika Gorica, 2000., str. 1863). Lexicon latinitatis medii aevi Iugoslaviae, donosi još i značenje rubac, što mi se ovdje čini boljim jer se ne radi o ručnicima nego upravo o »rupčićima«; Zagrabiae, MCMLXXIII, str. 698.

s0 Patena ili plitica - na njoj za vrijeme mise stoji euharistijski kruh /slika zdjele na posljednjoj večeri/; Anđelko BADURINA (ur.), Leksikon ikonografije zapadnog kršćanstva, IV. dop. izd., Kršćanska 
Calici d'oton dorati - $\quad$ - $\quad$ - $\quad$ - $\quad$ - $\quad$ - $\quad$ - $\quad$ - $\quad$ - $\quad$ - n. 3

Pozlaćeni mjedeni kaleži

3 kom.

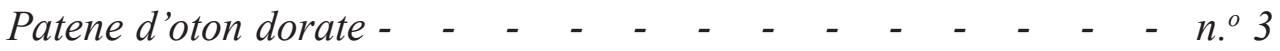

Pozlaćene mjedene patene

3 kom.

Borse da calice di diversi colori vechie - _ $\quad$ - $\quad$ - $\quad$ - $\quad$ - n. 6

$\begin{array}{ll}\text { Burse za kalež u različitim bojama } & 6 \text { kom. }\end{array}$

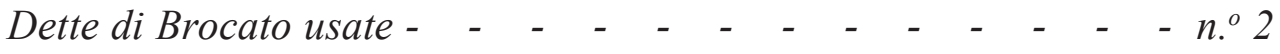

Rečene brokatne rabljene $\quad 2$ kom.

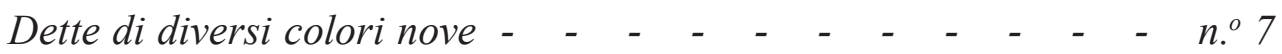

Rečene raznobojne nove $\quad 7$ kom.

Veli da calice di color rosso usati, e vechi - $\quad$ - $\quad$ - $\quad$ - $\quad$ - $\quad$ - $\quad n .^{\circ} 7$

Crveni velumi za kalež, rabljeni i stari 7 kom.

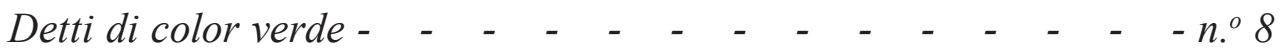

$\begin{array}{ll}\text { Rečeni [velumi] zelene boje } & 8 \mathrm{kom} .\end{array}$

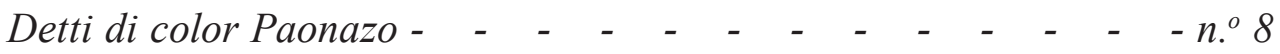

Rečeni ljubičaste boje 8 kom.

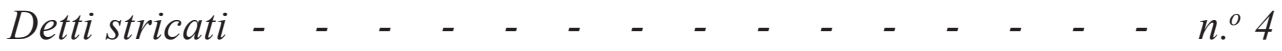

Rečeni prugasti ${ }^{51} \quad 4$ kom.

(fol. 1v)

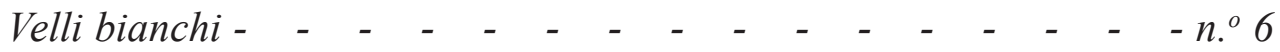

$\begin{array}{ll}\text { Bijeli velumi } & 6 \mathrm{kom} .\end{array}$

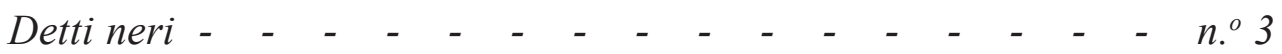

Rečeni crni [velumi] 3 kom.

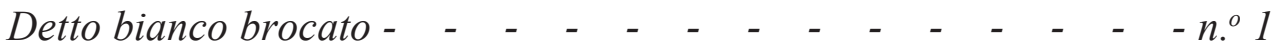

Rečeni bijeli [velum] brokatni 1 kom.

sadašnjost, Zagreb, 2000., str. 484.

51 U modernom talijanskom jeziku glagol striccare ne postoji. U raznim se rječnicima upućuje na izraz strigare, a značenje je razmrsiti, rasplesti (Mirko DEANOVIĆ - Josip JERNEJ, Talijansko-hrvatski rječnik, četrnaesto izdanje, Školska knjiga, Zagreb, 2002., str. 972). Moguće da je riječ i o vrsti tkanine a pelo strisciante. U tom smislu prvo značenje: »1.Tessuti a pelo strisciante Sono tessuti che presentano effetti di briglie sciolte formanti motivi decorativi. Questi effetti si ottengono con orditi supplementari, che si slegano formando un disegno, mentre al rovescio restano sciolti. Questi orditi possono essere messi anche solo dove servono per realizzare il disegno e, in questo caso, vengono detti "a disposizione" " $\mathrm{i}$ drugo značenje: »2. stricatura (o striccatura) s. f. [der. di stricare 2 (o striccare)]. - Nell'industria tessile, operazione di rifinizione, eseguita a umido sulla stricatrice, con la quale si conferisce al pelo della stoffa, sollevato dalla precedente garzatura, una direzione uniforme «. http://www.treccani.it/vocabolario/stricatura/. 


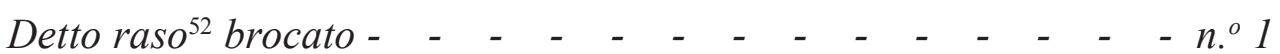

Rečeni brokatni saten

1 kom.

Detto grande nero di Passione da Spale - $\quad$ - $\quad$ - $\quad$ - $\quad$ - $\quad$ - n. 1

Rečeni veliki crni [velum] za ramena prigodom Muke

$1 \mathrm{kom}$

Ditti da spale bianchi usati - $\quad$ - $\quad$ - $\quad$ - $\quad$ - $\quad$ - $\quad$ - $\quad$ - $\quad$ - $\quad$ - $\quad$ - $n .^{\circ} 2$

Rečeni bijeli [velumi] za ramena, rabljeni 2 kom.

Tovaglie trà nove, usate, e lacerate - $\quad$ - $\quad$ - $\quad$ - $\quad$ - $\quad$ - n. 39

Novi, rabljeni i poderani oltarnici $39 \mathrm{kom}$.

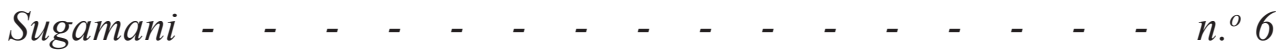

Ručnici

6 kom.

Un messal con rimesse d'Argento - $\quad$ - $\quad$ - $\quad$ - $\quad$ - $\quad$ - $\quad-\quad-n .^{\circ} 1$

Jedan misal sa srebrenim okovima 1 kom.

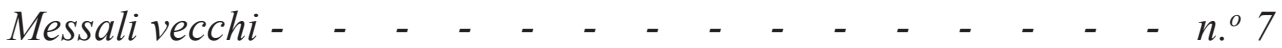

$\begin{array}{ll}\text { Stari misali } & 7 \text { kom. }\end{array}$

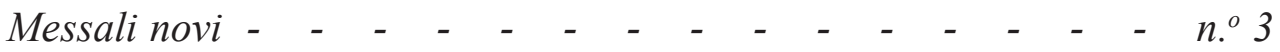

$\begin{array}{ll}\text { Novi misali } & 3 \mathrm{kom} .\end{array}$

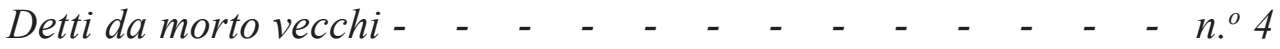

Stari [misali] za pokojne 4 kom.

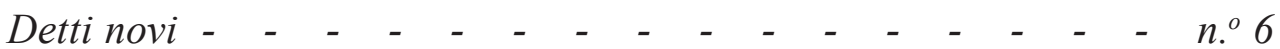

Novi [misali za pokojne]

6 kom.

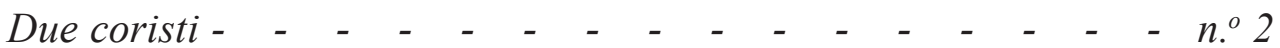

$\begin{array}{ll}\text { Dvije korske knjige } & 2 \text { kom. }\end{array}$

Breviarii grandi da Choro vechi - $\quad$ - $\quad$ - $\quad$ - $\quad$ - $\quad$ - $\quad$ - $\quad$ - $n .^{\circ} 4$

Četiri stara korska brevijara 4 kom.

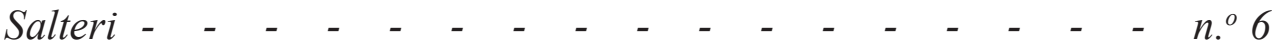

$\begin{array}{ll}\text { Psaltiri } & 6 \mathrm{kom} .\end{array}$

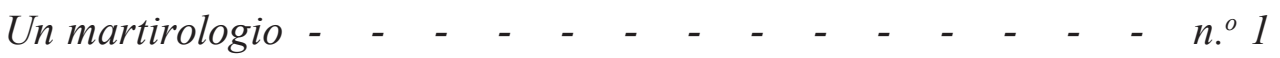

Jedan martirologij 1 kom.

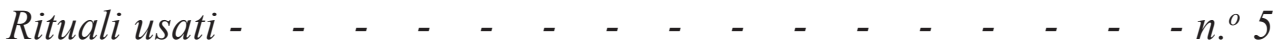

$\begin{array}{ll}\text { Rabljeni rituali } & 5 \text { kom. }\end{array}$

Stole paonazze, e bianche - $\quad$ - $\quad$ - $\quad$ - $\quad$ - $\quad$ - $\quad$ - $\quad$ - $\quad$ - $\quad$ n. 5

Štole ljubičaste i bijele 5 kom.

52 Tal. raso $=$ saten, vrsta tkanine posebnoga veza niti; DEANOVIĆ - JERNEJ, Talijansko-hrvatski rječnik..., str. 785. 
Borse con sue mandole d'Argento, e Purificatoi - $\quad-\quad-\quad-\quad-n .^{\circ} 5$

Burse (kutije) sa svojim srebrenim posudama i purifikatorijima

5 kom.

Borse d'oglio santo con suoi vaseti d'Argento e Purificatoi - $\quad$ - $\quad n .^{\circ} 5$

Kutije za sveto ulje sa svojim srebrenim posudicama i purifikatorijima

5 kom.

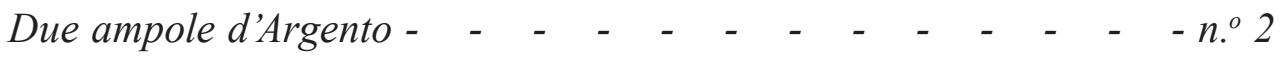

$\begin{array}{ll}\text { Dvije srebrene ampulice } & 2 \mathrm{kom} .\end{array}$

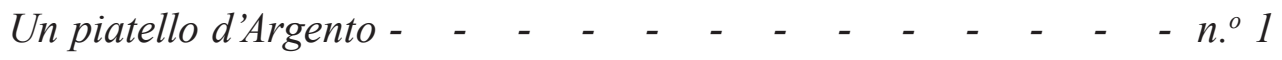

Jedan srebreni tanjurić

1 kom.

Una canevetta con vasi tre d'argento per ogli santi - $\quad$ - $\quad$ - $\quad$ - n. ${ }^{\circ} 1$

Jedna kutijica s tri srebrene posudice za sveta ulja 1 kom.

Un Turibolo d'argento con sua navicella, e cuchiaro - $\quad$ - $\quad$ - $n .^{\circ} 1$

Jedna srebrena kadionica sa svojom srebrenom navikulom i žličicom 1 kom.

Un sechielo ${ }^{53}$ d'Argento con suo Aspersorio - $\quad$ - $\quad$ - $\quad$ - $n .^{\circ} 1$

Srebrena škropionica sa škropilom (aspergilom) $\quad 1 \mathrm{kom}$.

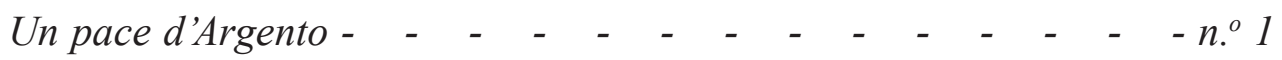

Jedan srebreni 'Pax'54 $1 \mathrm{kom}$.

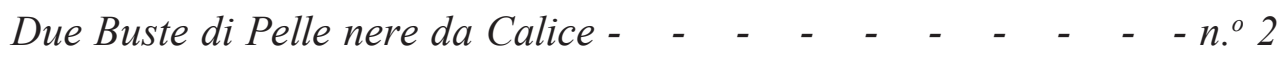

Dvije kutije od crne kože za kalež 2 kom.

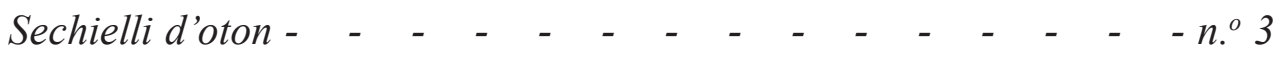

$\begin{array}{ll}\text { Škropionice od žute mjedi } & 3 \mathrm{kom} .\end{array}$

Lavello di Rame con suo sechiello pur di rame e fero al muro - $\quad$ - n. ${ }^{\circ} 1$

Mjedeni umivaonik sa svojom posudom od mjedi i željeza, pričvršćen na zid 1 kom.

$(2 \mathrm{r})$

Croci d'Argento una delle quali è rotta - $\quad$ - $\quad$ - $\quad$ - $\quad$ - $\quad$ - $n .^{\circ} 3$

Srebreni križevi, od kojih je jedan razbijen 3 kom.

53 Secchièllo s. m. [dim. di secchio] u smislu prvoga značenja: »1. In genere, secchio di piccole dimensioni, per usi varî: $s$. da ghiaccio (o s. portaghiaccio), di metallo o di cristallo, nel quale si mettono i cubetti di ghiaccio per rinfrescare, a tavola, le bevande, o in cui, se di dimensioni maggiori, si tengono in fresco le bottiglie di vino bianco o di spumante; s. per l'acqua benedetta, di materiale vario, anche prezioso, spesso artisticamente decorato, usato nelle funzioni della liturgia cattolica per contenervi l'acqua benedetta; in partic., il piccolo secchio, un tempo di latta verniciata ora di plastica, con il quale i bambini giocano al mare, trasportandovi acqua e sabbia«. http://www.treccani.it/vocabolario/secchiello/.

54 Pacifikal (lat. pacificalis »mirotvorni, onaj koji donosi mir«). Križ na nisku stalku koji biskup ili svećenik u određenim prigodama nosi u ruci (npr. kod blagoslova kuća) i njime blagoslivlja vjernike (BADURINA (ur.), Leksikon ikonografije..., str. 476). Možda se ovdje radi o srebrenoj pločici s likom Krista ili nekoga od svetaca, koju je ranije svećenik davao na poljubac u određenim prigodama, nakon što izgovori: Pax Domini sit semper vobiscum (npr. mladencima prigodom vjenčanja). 
Altre Croci con piede e lastra (?) d'Argento usate - $\quad$ - $\quad$ - $\quad$ - $\quad$ n. 4

Drugi rabljeni križevi s postoljem i srebrenim podnožjem (?)

4 kom.

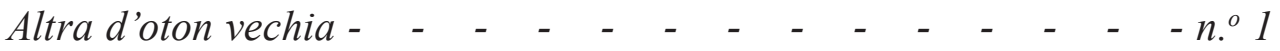

Jedan stari srebreni [križ]

1 kom.

Lampade grandi d'Argento -

2 kom.

Velike srebrene svjetiljke

Dette d'otton usate, e vechie - $\quad$ - $\quad$ - $\quad$ - $\quad$ - $\quad$ - $\quad$ - $n .^{\circ} 10$

Rečene rabljene i stare, od žute mjedi

10 kom.

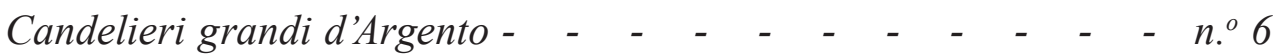

Veliki srebreni oltarni svijećnjaci

6 kom.

Detti d'oton compresi queli delle Chiese campestri - - - $\quad$ - $\quad n .^{\circ} 38$

Navedeni od mjedi, uključeni i oni iz seoskih crkava

38 kom.

Il Battisterio con sua conca di rame nova, salarieta d'Argento

con coperchio, e Cazzetta d'Argento per battezzare - $\quad$ - $\quad$ - $\quad n .^{\circ} 1$

Krstionica s novim mjedenim koritom, sa srebrenom posudicom

za sol s poklopcem i srebrenom posudicom za krštavanje

1 kom.

Piatelli d'oton $n .^{\circ} 5$ compreso uno rotto - $\quad$ - $\quad$ - $\quad-\quad-n .{ }^{\circ} 5$

Pet mjedenih tanjurića uključujući i jedan razbijeni 5 kom.

Una cazza di ramo vecchia - $\quad$ - $\quad$ - $\quad$ - $\quad$ - $\quad$ - $\quad$ - n. ${ }^{\circ} 1$

Jedna stara mjedena posuda

1 kom.

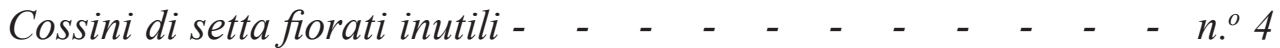

Svileni jastučići na cvjetiće, neuporabivi 4 kom.

Un Baldachin di setta fiorato con suoi fiochi d'oro e mazze

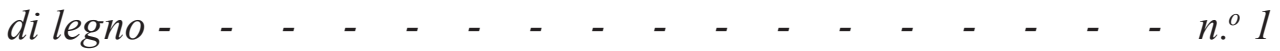

Jedna svilena nebnica (baldahin) na cvjetiće sa svojim zlatnim

resama i drvenim motkama

1 kom.

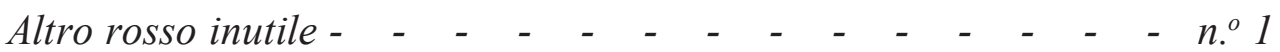

Jedna crvena neuporabljiva [nebnica] 1 kom.

Una ombrela vecchia di setta - $\quad$ - $\quad$ - $\quad$ - $\quad$ - $\quad$ - $\quad$ - $\quad$ - n. 1

Jedno staro svileno procesijsko sjenilo $1 \mathrm{kom}$.

Un Pivial con sua Stola di Drappo à Fiori bianchi e Rossi - $\quad$ - $\quad$ - n. ${ }^{\circ} 1$

Jedan pluvijal sa svojom štolom od tkanine na bijele i crvene cvjetove

Un altro novo bianco con sua stola - - $\quad$ - $\quad$ - $\quad$ - $\quad n .^{\circ} 1$

Jedan bijeli [pluvijal] sa svojom štolom 1 kom. 


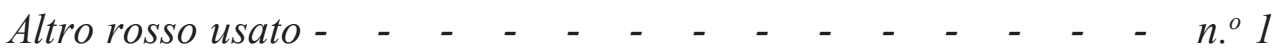

Jedan rabljeni crveni [pluvijal]

1 kom.

Altro nero con sua stola, e tonicelle simili - $\quad$ - $\quad$ - $\quad$ - $n .^{\circ} 1$

Jedan crni pluvijal sa svojom sličnom štolom i tunicelama $1 \mathrm{kom}$.

Una muda ${ }^{55}$ di tabelle con color di lapis lazaro usata - $\quad$ - $\quad$ - $n .^{\circ} 1$

Jedna muda tablica plave ${ }^{56}$ boje, rabljena $1 \mathrm{kom}$.

Altra muda con suase dorate - $\quad$ - $\quad$ - $\quad$ - $\quad$ - $\quad$ - $\quad$ - n. 1

Jedna muda s pozlaćenim suase (okvirom ili koricama) $1 \mathrm{kom}$.

Pezze di tella per coprir gl'altari - $\quad$ - $\quad$ - $\quad$ - $\quad$ - $\quad$ - $\quad$ - $\quad$ - n. 5

Komadi platna za pokrivanje oltarâ $\quad 5$ kom.

Un Tabernacolo di Legno - $\quad$ - $\quad$ - $\quad$ - $\quad$ - $\quad$ - $\quad$ - $\quad$ - $\quad$ - $\quad$ - $\quad$ - $n .^{\circ} 1$

Jedno drveno svetohranište $1 \mathrm{kom}$.

Cussini di Coridoro usati - $\quad$ - $\quad$ - $\quad$ - $\quad$ - $\quad$ - $\quad$ - $\quad$ - $\quad$ - $\quad$ - $\quad$ - n. ${ }^{\circ} 5$

Jastuci od pozlaćene (puncirane) kože 5 kom.

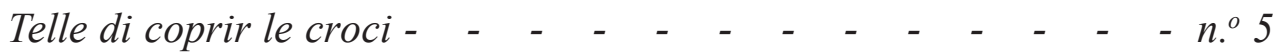

Platna za pokrivanje križeva $\quad 5$ kom.

Un Aparato di Drappo usato di Brocado d'oro con tonicelle,

due stole e tre manipoli, un con fondi bianco - $\quad-\quad-\quad-\quad-\quad-n .^{\circ} 1$

Jedan komplet od istrošene tkanine zlatnoga brokata s tunicelama,

dvije štole i tri manipula, jednim na bijeloj postavi

1 kom.

Apparato rosso con due Tonicelle ed un manipolo simili - $\quad$ - $\quad n .^{\circ} 1$

Crveni komplet s dvjema sličnim tunicelama i manipulom 1 kom.

Altro detto bianco di damasco con sue Tonicelle, una

stola e due manipoli il tutto vechio - $\quad$ - $\quad$ - $\quad$ - $\quad$ - $\quad-\quad-\quad-n .^{\circ} 1$

Drugi rečeni bijeli od damasta sa svojim tunicelama, jednom

štolom i dva manipula - sve staro

1 kom.

Altro detto da morto di seda senza stola con due Tonicelle - $\quad$ - $\quad$ - $n .^{\circ} 1$

Drugi rečeni za pokojne, od svile, bez štole s dvije tunicele 1 kom.

\footnotetext{
55 Nije jasno o čemu se radi. U talijanskom jeziku riječ muda znači: mitarenje, linjanje, mijenjanje - perja; DEANOVIĆ - JERNEJ, Talijansko-hrvatski rječnik..., str. 621.

56 Boja lapis lazulia.
} 
$(2 \mathrm{v})$

Una Pianeta à fiori d'oro con fondi gialo e fodra verde

con sua stola e manipolo il tutto usato - $\quad$ - $\quad$ - $\quad$ - $\quad-\quad-\quad-n .^{\circ} 1$

Jedna misnica sa zlatnim cvjetovima na žutoj podlozi i zelenoj podstavi

sa svojom štolom i mnipulom, sve rabljeno

1 kom.

Altra detta di Brocato d'oro color di rosa con stola e manipolo - $\quad n .^{\circ} 1$

Druga od zlatnoga brokata ružičaste boje sa štolom i manipulom

1 kom.

Altra detta di Veludo rosso con suo manipolo senza stola vecchia - n. ${ }^{\circ} 1$

Druga od crvenoga baršuna sa svojim manipulom bez stare štole

$1 \mathrm{kom}$.

Una Pianetta rossa à fiori di lana con sua stola e manipolo - $\quad$ - $n .^{\circ} 1$

Jedna crvena misnica na cvjetove od vune sa svojom štolom i manipulom 1 kom.

Altre due rosse con fiori giali, due tonicelle simili senza stola - $\quad$ - n. ${ }^{\circ} 2$

Druge dvije crvene sa žutim cvjetićima s dvjema sličnim tunicelama bez štole 2 kom.

Altr dett di Amavero color di pietra amarizzato ${ }^{57}$

con fodra Latisina, stola e manipolo - $\quad$ - $\quad$ - $\quad$ - $\quad$ - $\quad$ - $n .^{\circ} 1$

Druga rečena tamnocrvene boje s

podstavom od latisina, sa štolom i manipulom

$1 \mathrm{kom}$.

Altre dette fiorate di Ferandina58 di fondi bianco à Striche,

con sue stole e manipolo il tutto vechio - - $\quad$ - $\quad$ - $\quad$ - $\quad$ - $\quad n .^{\circ} 4$

Druge rečene na cvjetove od ferandine na bijeloj prugastoj podlozi

sa svojim štolama i manipulima - sve staro

4 kom.

Altra fiorata con fondi bianco lacera - $\quad$ - $\quad$ - $\quad$ - $\quad$ - $\quad$ - $n .^{\circ} 1$

Druga na cvjetove s bijelom podlogom, poderana $1 \mathrm{kom}$.

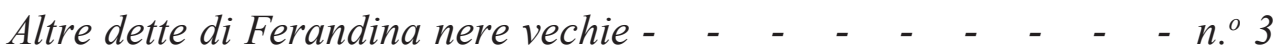

Druge rečene od crne ferandine, stare 3 kom.

Dette nove con due Tonicelle - $\quad$ - $\quad$ - $\quad$ - $\quad$ - $\quad$ - $\quad$ - $\quad$ - $\quad$ - n. 2

$\begin{array}{ll}\text { Rečene nove s dvjema tunicelama } & 2 \mathrm{kom} .\end{array}$

Dette di Ferandina paonace con due Tonicelle vechie - $\quad$ - $\quad$ - $\quad$ - n. ${ }^{\circ} 2$

Rečene od ljubičaste ferandine s dvjema tunicelama, stare 2 kom.

57 L'amaranto è un colore tra il rosso scarlatto e il cremisi (per certi versi accostabile al granata, ma più rossastro), tipico dei fiori dell'amaranto, pianta ornamentale del genere della famiglia delle Amarantacee (Amarantus caudatus) con infiorescenze a spiga di colore rosso scuro, comunemente detta "erba meraviglia”. Doretta DAVANZO POLI, I Mestieri della Moda a Venezia nei sec. XIII-XVIII, Glossario, Venezia, 1984-86.

58 Ferandina, ferrandina, stoffa leggera di lana e seta (trama di lana, catena di seta/ potka od vune, a osnova od svile). Tessuto di seta inferiore (manje vrijedna svilena tkanina); Luca MOLLA, The silk industry of renaissance Venice. Glossary, Johns Hopkins University Press, Baltimore - London, 2000. 
Dette nove paonace con due Tonicele - $\quad-\quad{ }_{-} \quad-\quad-\quad-\quad-n .^{\circ} 2$

$\begin{array}{ll}\text { Rečene nove ljubičaste s dvjema tunicelama } & 2 \text { kom. }\end{array}$

Tonicelle di seta color violeto vechie - $\quad$ - $\quad$ - $\quad$ - $\quad$ - $\quad$ - $\quad$ - $\quad$ - $n .^{\circ} 2$

Stare tunicele od ljubičaste svile 2 kom.

Dette verdi vecchie, et inutili con sue stole, e manipoli - $\quad-\quad-\quad-n .^{\circ} 2$

Navedene zelene stare i neuporabljive sa svojim štolama i manipulima 2 kom.

Il stendardo di San Nicolò novo - $\quad$ - $\quad$ - $\quad$ - $\quad$ - $\quad$ - $\quad$ - $\quad$ - $n .^{\circ} 1$

Novi barjak svetoga Nikole $1 \mathrm{kom}$.

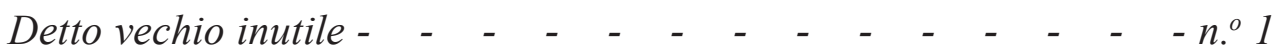

Navedeni stari, neuporabljiv 1 kom.

Parapetti di seda rossi vechi - $\quad$ - $\quad$ - $\quad$ - $\quad$ - $\quad$ - $\quad$ - $\quad$ - $\quad$ - $n .^{\circ} 3$

Stari crveni svileni parapeti 3 kom.

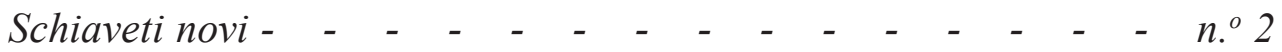

$\begin{array}{ll}\text { Novi šćaveti } & 2 \mathrm{kom} .{ }^{59}\end{array}$

Una chioca d'otton vecchia non inutile - $\quad$ - $\quad$ - $\quad$ - $\quad$ - $\quad$ - $n .^{\circ} 1$

Jedna stara 'ćoka' ${ }^{60}$ od žute mjedi, uporabljiva ${ }^{61} \quad 1 \mathrm{kom}$.

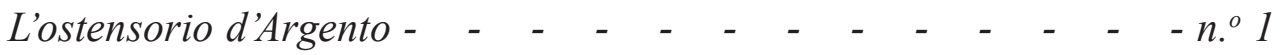

Srebrena pokaznica 1 kom.

La Piside d'Argento dorata con suo padiglion di drappo - $\quad$ - $\quad$ - n. ${ }^{\circ} 1$

Pozlaćeni srebreni ciborij s velumom od svilene tkanine $1 \mathrm{kom}$.

Reliqiarii d'argento con sue Reliquie due grandi e un picolo - $\quad$ - n. 3

Srebreni relikvijari sa svojim relikvijama, dva velika i jedan mali 3 kom.

Due tapedi di lana vechi - $\quad-\quad$ - $\quad$ - $\quad$ - $\quad$ - $\quad$ - $\quad$ - $\quad$ - n. 2

$\begin{array}{ll}\text { Dva stara vunena tepiha } & 2 \mathrm{kom} .\end{array}$

Crocifissi uno de'queli, grande - $\quad$ - $\quad$ - $\quad-\quad-\quad-\quad$ - $\quad$ -.$^{\circ} 5$

Križevi, od kojih jedan velik $\quad 5$ kom.

(fol. 3r)

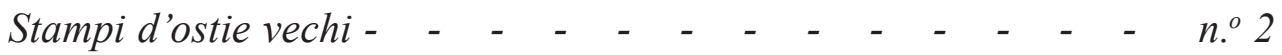

Stari kalupi za hostije 2 kom.

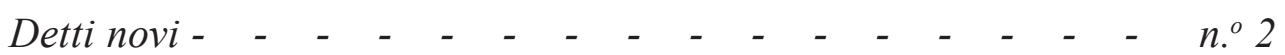

Novi [kalupi za hostije] 2 kom.

59 Šćavet - knjiga misnih čitanja: poslanica i evenđelja pisane pučkim hrvatskim jezikom zapadnoga narječja; Jeronim ŠETKA, Hrvatska kršćanska terminologija, MARIJA, Split, 1976., reprint, str. 307.

60 Svijećnjak s više svijeća.

${ }^{61}$ Možda je pisar ipak mislio napisati samo inutile. 
Un ferro di tondar particelle - $\quad-\quad-\quad-\quad-\quad-\quad-\quad-\quad-n .^{\circ} 1$

Željezo za obrezivanje čestica ${ }^{62} \quad 1$ kom.

Telle cerate sopra gl'Altari - $\quad$ - $\quad$ - $\quad$ - $\quad$ - $\quad$ - $\quad$ - $\quad$ - $n .^{\circ} 8$

$\begin{array}{ll}\text { Navoštena platna za pokrivanje oltara } & 8 \mathrm{kom} .\end{array}$

Ferali di rame dorati usati con sue aste rotte - $\quad$ - $\quad$ - $\quad$ - n. 4

Rabljeni fenjeri od pozlaćene mjedi sa svojim razbijenim motkama

4 kom.

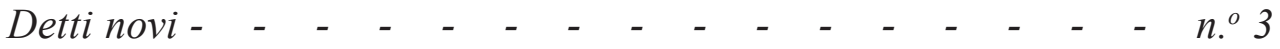

Navedeni novi

3 kom.

Detti di latta vechi da mano - $\quad$ - $\quad$ - $\quad$ - $\quad$ - $\quad$ - $\quad$ - $\quad$ - n. 3

Stari navedeni od lima ručni

3 kom.

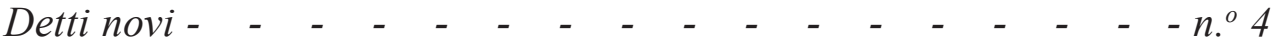

Navedeni novi

4 kom.

Croci di legno da morto con sue aste - $\quad$ - $\quad$ - $\quad$ - $\quad$ - $\quad$ - $\quad$ - n. 5

Mrtvački drveni križevi sa svojim motkama 5 kom.

Campanelle da mano vecchie - $\quad$ - $\quad$ - $\quad$ - $\quad$ - $\quad$ - $\quad$ - $\quad$ - $n .{ }^{\circ} 8$

Stari ručni zvončići

8 kom

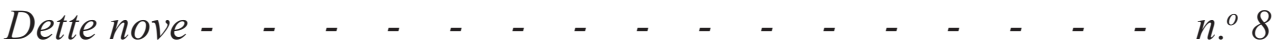

Navedeni novi

8 kom.

Una statua nova della B. $V$. del Rosario

con sua tenda da coprire la stessa - $\quad$ - $\quad$ - $\quad$ - $\quad$ - $\quad$ - $\quad$ - $\quad$ - n. 1

Jedan novi kip Blažene Djevice od Ružarija s tkaninom za pokrivanje istoga

1 kom.

Due ottavarii novi - $\quad$ - $\quad$ - $\quad$ - $\quad$ - $\quad$ - $\quad$ - $\quad$ - $\quad$ - $\quad$ - $\quad$ - $n .^{\circ} 2$

Dva nova 'oktovara'63 2 kom.

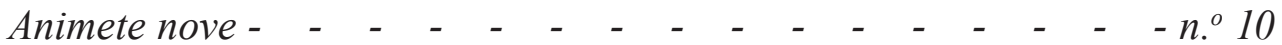

Nove pale [za kalež]

10 kom. $\left.{ }^{64}\right)$.

62 Misli se: hostije.

63 Vjerojatno se radi o knjigama osmodnevne pobožnosti (ottavario-osmodnevna pobožnost); DEANOVIĆ - JERNEJ, Talijansko-hrvatski rječnik..., str. 665.

64 Prigodom održavanja navedenoga simpozija 3. prosinca 2011. profesorica Nina Kudiš sa suradnicima i župnikom Miroslavom Paraniakom priredila je vrlo dojmljivu izložbu crkvenoga ruha i liturgijskih predmeta. Uspoređujući ovaj inventar s onim što je ondje bilo prikazano, vidljivo je da je praktički sve sačuvano, od srebrnine i svijećnjakâ do vrijedne liturgijske odjeće itd. Postavlja se pitanje što je to bilo sakriveno u grobnici i je li uopće nešto bilo sakriveno? Očito ne stoji legenda koju navodi Petar Strčić u kojoj spominje jedno mišljenje barbanskoga puka da je Stanković opljačkao crkvenu imovinu koja je prigodom francuske okupacije bila sakrivena u župnoj crkvi u jednoj grobnici: »Pljačka crkvenih dragocjenosti odmah je povezana sa sve većim Stankovićevim bogatstvom; narod je zaključio da je pljačku izvršio sam kanonik, i tako obogatio sebe i svoje.« U zagradama, pak, dodaje sljedeće: »Sa zahvalnošću se sjećam podatka koji mi je o toj narodnoj legendi /istaknuo J. Jelinčić/ bio dao sada pokojni Miko Bonifačić Rožin iz Instituta za narodni život i umjetnost u Zagrebu« (STRČIĆ, Petar Stanković..., str. 150; usp. i Domenico CERNECCA, »Petar Stanković«, Jadranski zbornik, sv. 4, Ri- 


\section{SAŽETAK \\ Župni (kaptolski) arhiv Barbana, s osvrtom na podatke o kanoniku Petru Stankoviću}

Autor u prilogu govori o brizi poglavarâ Katoličke Crkve za očuvanje arhivskoga gradiva te o važnosti samih crkvenih arhiva. Nabraja razne vrste crkvenih arhiva i govori o njihovoj važnosti kako bi se olakšalo proučavanje prošlosti. Govori o sačuvanosti gradiva barbanskoga kaptolskog odnosno župnoga arhiva te o važnosti pojedinih njegovih dijelova, naglašavajući važnost knjiga pisama, knjiga oporuka, knjiga raznih ugovora, knjiga kaptolskih zakupa te raznih spisa koje još treba srediti, detaljno pregledati i evidentirati te daje osnovne podatke o popisivanju crkvenih arhiva na području Porečke i Pulske biskupije koje su u zajedničkoj suradnji obavili Arhiv u Pazinu i Porečka i Pulska biskupija. Posebno navodi neke podatke iz knjige sadržaja oporuka, knjige registra pisama i matičnih knjiga, posebno iz knjiga umrlih. Na temelju vrlo vrijedne knjige sadržaja oporuka navodi podatke o starim barbanskim prezimenima koja su, uglavnom, hrvatska, a manjim dijelom talijanska. Osvrće se posebno na Knjigu registra pisama koju je vodio kanonik Petar Stanković, navodeći neke od njihovih sadržaja, posebno one koji se odnose na Stankovićeva izvješća o broju stanovnika, o učiteljima, o grobljima itd. Iz matičnih knjiga umrlih donosi više upisa o smrti raznih kanonika i drugih svećenika. Posebno se osvrće na navedenoga poznatog barbanskog svećenika, kanonika i znanstvenika Petra Stankovića. Daje razne podatke iz matičnih knjiga o tom kanoniku te njegovoj užoj i široj obitelji otkrivajući neke nove činjenice. Daje popis sve rođene djece Petrovih roditelja, Antuna Stankovića i supruge mu Notburge rođene Martinić, te podatke o Antunovu ponovnom vjenčanju nakon više od dvadeset godina od prerane Notburgine smrti. Navodi također podatke o bračnom paru Aleksandra d'Ellettija, barbanskom kancelaru, i Andrijani, rođenoj Stanković, Petrovoj sestri, te daje podatke o njihovoj djeci. Na kraju u izvorniku i u prijevodu donosi dva priloga: povelju o posveti crkve i inventar crkvenoga namještaja i liturgijskoga ruha iz 1750. godine.

jeka - Pula, 1960., str. 19). Pokušajmo malo promisliti: nije li moguće da je netko, znajući gdje se nalazi »blago«, otvorio grobnicu i opljačkao ga, a onda sve svalio na Stankovića? No, na temelju usporedbe Inventara koji je sačinjen kada kanonik Stanković još nije bio rođen (otac mu je bio rođen tri godine prije nastanka ovoga inventara), »legenda« očito »pada u vodu«. 


\section{SUMMARY}

\section{Parish (Chapter) Archives of Barban, with reference to the information on Canon Petar Stanković}

The author of the paper speaks of the concern of the heads of the Catholic Church to preserve the archives and of the importance of the church archives. He lists various types of church archives and talks about their importance in facilitating the study of history. The author speaks about the preservation of the archives of the Barban chapter or parish archives and the importance of some of its parts, emphasizing the importance of the book of letters, the book of last wills, the book of various contracts, the book of chapter's leases and various records, which need to be arranged, reviewed in detail and recorded. He also gives basic information on the listing of church archives in the area of Poreč and Pula Diocese, which was carried out jointly by the Archives of Pazin and the Poreč and Pula Diocese. Specifically, he cites some information from the book of the contents of last wills, the book of the register of letters and the registers of births, marriages and deaths, especially from the registers of deaths. Based on the very valuable book of the contents of last wills, he lists information about old Barban surnames, which are mostly Croat and, to a lesser extent, Italian. Special mention is made of the Book of the register of letters, kept by Canon Peter Stanković, citing some of their contents, in particular those related to Stanković's reports of the population, teachers, cemeteries, etc. He brings several entries on the death of various canons and other priests recorded in the registers of deaths. He particularly addresses the famous Barban priest, canon and scientist Petar Stanković, giveing various information recorded in the registers about this canon, his immediate and extended family, revealing some new facts. He gives a list of all children born to Petar's parents, Antun Stanković and his wife Notburga née Martinić, and information about Antun's second marriage more than twenty years from after the premature death of Notburga. He also mentions details about the married couple Aleksandar d'Elletti, the chancellor of Barban, and Andrijana, born Stanković, the sister of Petar, and provides information about their children. Finally, the author adds two appendices in the original and in the translation: a church consecration charter and an inventory of church furniture and vestments from 1750. 


\section{RIASSUNTO \\ Archivio parrocchiale (capitolare) di Barbana con cenni sui dati relativi al canonico Petar Stanković}

L'autore nell'articolo parla della cura che prendono i capi della Chiesa Cattolica per conservare il materiale archivistico e dell'importanza degli archivi ecclesiastici. Elenca vari tipi di archivi ecclesiastici e parla della loro importanza nel facilitare lo studio della storia. Parla dello stato di conservazione del materiale proveniente dall'archivio capitolare ossia parrocchiale di Barbana e dell'importanza di alcune sue parti, mettendo in rilievo l'importanza dei libri di lettere, libri di testamenti, libri di contratti vari, libri di appalti capitolari e di vari atti che bisogna sistematizzare, analizzare dettagliatamente e registrare e riporta dati fondamentali relativi all'inventariazione degli archivi ecclesiastici sul territorio della Diocesi di Parenzo e Pola che, in collaborazione, hanno effettuato l'Archivio di Pisino e la Diocesi di Parenzo e Pola. Riporta, in particolare, alcuni dati dal libro dei contenuti di testamenti, dal libro del registro delle lettere e dai registri anagrafici, in particolare dal registro dei defunti. In base a un libro dei contenuti di testamenti molto importante riporta dati relativi agli antichi cognomi di Barbana che per lo più sono croati, e in una parte minore italiani. Si riferisce particolarmente al Libro del registro di lettere redatto dal canonico Petar Stanković, citando alcuni dei contenuti, soprattutto quelli che riguardano le relazioni di Stanković sul numero di abitanti, sui maestri, sui cimiteri, ecc. Dai registri dei defunti riporta diverse iscrizioni relative alla morte di vari canonici e altri sacerdoti. In particolare si fa cenno al citato noto sacerdote di Barbana, canonico e scienziato, Petar Stanković. Riporta vari dati dai registri sul canonico e sulla sua famiglia, stretta e larga, scoprendo in questo modo alcuni fatti nuovi. Riporta l'elenco di tutti i figli nati dei genitori di Petar, di Antun Stanković e di sua moglie Notburga, nata Martinić, nonché dati relativi al secondo matrimonio di Antun dopo più di vent'anni dalla scomparsa prematura di Notburga. Inoltre, riporta i dati sui coniugi Alessandro d'Elletti, il cancelliere di Barbana, e Andriana, nata Stanković, la sorella di Petar, riportando i dati sui loro figli. In fine, nell'originale e nella traduzione, riporta due allegati: la carta sulla cerimonia di consacrazione della chiesa e l'inventario di arredamento ecclesiastico e di paramenti liturgici del 1750. 